\title{
Kingdom of Swaziland: Staff Monitored Program-Staff Report; Staff Supplement
}

In the context of the Kingdom of Swaziland - 2011 Staff Report for the Staff Monitored Program, the following documents have been released and are included in this package:

- $\quad$ The staff report for the Kingdom of Swaziland - 2011 Staff Report for the Staff Monitored Program, prepared by a staff team of the IMF, following discussions that ended on March 2, 2011, with the officials of the Kingdom of Swaziland on economic developments and policies. Based on information available at the time of these discussions, the staff report was completed on April 4, 2011. The views expressed in the staff report are those of the staff team and do not necessarily reflect the views of the Executive Board of the IMF.

- $\quad$ An Informational Annex to the Staff Report of April 4, 2011.

The document listed below has been or will be separately released.

Letter of Intent, Memorandum of Economic and Financial Policies, and the Technical Memorandum of Understanding, sent to the IMF by the authorities of the Kingdom of Swaziland*

*Also included in Staff Report

The policy of publication of staff reports and other documents allows for the deletion of market-sensitive information.

Copies of this report are available to the public from

International Monetary Fund • Publication Services $70019^{\text {th }}$ Street, N.W. • Washington, D.C. 20431

Telephone: (202) 623-7430 • Telefax: (202) 623-7201

E-mail: publications@imf.org Internet: http://www.imf.org

\section{International Monetary Fund Washington, D.C.}




\title{
INTERNATIONAL MONETARY FUND
}

\section{KINGDOM OF SWAZILAND}

\author{
Staff-Monitored Program \\ Prepared by the African Department \\ in consultation with Other Departments
}

Approved by Sharmini Coorey and Jan Kees Martijn

April 4, 2011

Mission. A staff team-J. Mongardini (head), O. Basdevant, J. Karangwa, and B. Mircheva (all AFR)_visited Mbabane from February 16 to March 2, 2011 to discuss a Staff-Monitored Program (SMP) with the Kingdom of Swaziland. The mission met with Prime Minister B. Dlamini, Finance Minister M. Sithole, Economic Planning and Development Minister Prince Hlangusempi, Central Bank Governor M. Dlamini, other senior officials, and representatives of the donor community, labor unions, parliamentarians, and the press. It presented the mission's findings to the government in a cabinet meeting on March 1, 2011. The mission was joined by representatives of the African Development Bank (AfDB) and the World Bank (WB).

Past advice. The last Article IV consultation was concluded on January 10, 2011. Directors stressed the need to restore fiscal sustainability, improve competitiveness, and strengthen financial supervision. They called for additional measures in the 2011/12 budget to compensate for recent increases in non-priority spending and continued low revenue transfers from the Southern African Customs Union (SACU). They also called for stepped up efforts to improve the business environment, including by reviving the government's privatization program, reducing the cost of doing business, and keeping labor costs in line with those in the region.

SMP. In the attached Letter of Intent, dated March 29, 2011, the authorities request an SMP covering the period January 2011-June 2011. The objective of the SMP is to build a strong track record of fiscal consolidation and structural reforms to support the authorities' possible request for a formal Fund arrangement in late 2011.

Exchange system. Conventional peg. Swaziland maintains one exchange restriction subject to approval under Article VIII. This arises from the 33.33 percent limit for advance payments for the import of certain capital goods.

Outreach. The mission attended the budget speech in parliament on February 18, made two presentations during an open seminar on the budget organized by the Minister of Finance on Wednesday, February 23, gave a press conference to the local media, and visited a local school.

Main Authors: J. Mongardini, O. Basdevant, J. Karangwa, and B. Mircheva. 
Glossary. 3

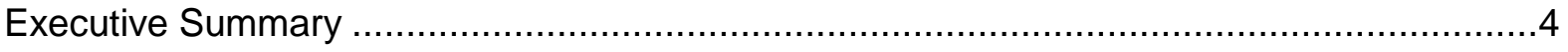

I. Recent Economic Developments and Short-Term Outlook .........................................

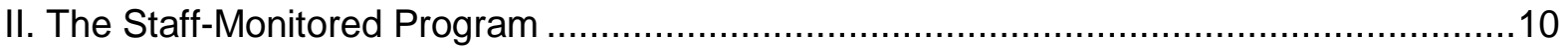

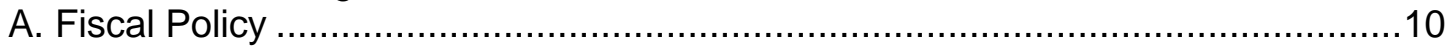

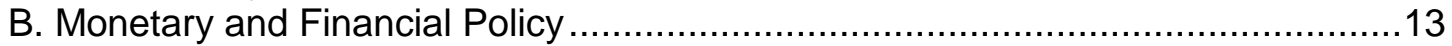

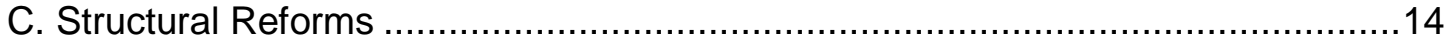

III. Objectives and Risks to the Implementation of the SMP ..........................................14

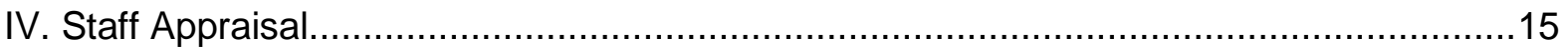

\section{TABLES}

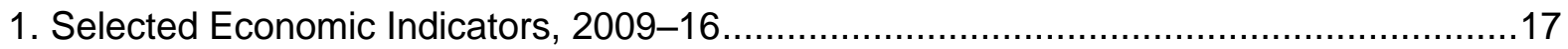

2. Fiscal Operations of the Central Government, 2009/10-17 ....................................18

3. Fiscal Operations of the Central Government 2009/10-17 ........................................19

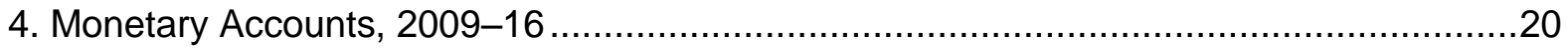

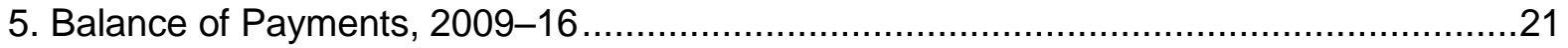

FIGURES

1. Recent Economic Developments and Regional Comparison .......................................

2. Fiscal Balance, Current Account Balance .............................................................

3. The Fiscal Crisis is Unfolding into an External Crisis ...............................................

4. Policy Rate of the Central Bank of Swaziland and Private Sector Developments ..............9

5. The Banking sector is weathering well the financial crisis .........................................

\section{BOXES}

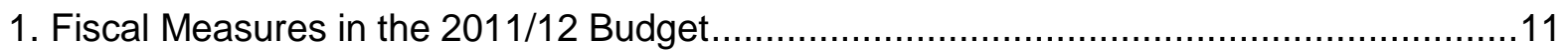

\section{APPENDIXES}

1. Letter of Intent

\section{ATTACHMENTS}

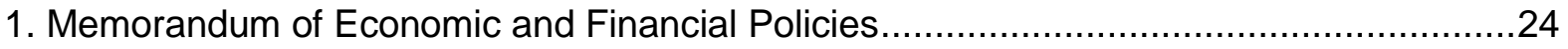

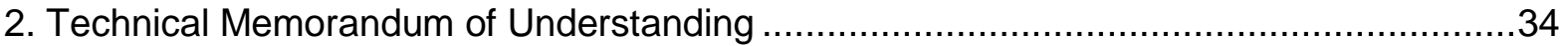




\section{GLOSSARY}

AfDB

AIDS

BLNS

CBS

CGER

CMA

CPI

CTA

DSA

EVERS

ES

FAR

FDI

HIV

MOF

$M B$

MDGs

NBFI

PFM

PPPs

REER

SACU

SARB

SMES

SMP

SRA

TA

WB
African Development Bank

Acquired Immunodeficiency Syndrome

Botswana, Lesotho, Namibia, and Swaziland

Central Bank of Swaziland

Consultative Group on Exchange Rates

Common Monetary Area

Consumer price index

Central Transport Authority

Debt Sustainability Analysis

Enhanced Voluntary Early Retirement Scheme

External Sustainability

Fiscal Adjustment Roadmap

Foreign Direct Investments

Human Immunodeficiency Virus

Ministry of Finance

Macroeconomic Balance

Millennium Development Goals

Nonbank Financial Institutions

Public Financial Management

Public Private Partnerships

Real Effective Exchange Rate

Southern African Customs Union

South African Reserve Bank

Small- and Medium-sized Enterprises

Staff-Monitored Program

Swaziland Revenue Authority

Technical Assistance

World Bank 


\section{EXECUTIVE SUMMARY}

Swaziland is in a full fiscal crisis, which is endangering external stability. Driven by a drop in Southern Africa Customs Union (SACU) revenue, one of the highest wage bills in Sub-Saharan Africa, and weaknesses in expenditure controls, the overall fiscal deficit is expected to reach about 13 percent of GDP in the fiscal year 2010/11 ending in March 2011. In order to finance the deficit, the government has accumulated a large amount of domestic arrears and drained the gross official reserves of the Central Bank of Swaziland, which could call into question the parity of the lilangeni with the South African rand.

In response to the crisis, the government of Swaziland has submitted a conservative 2011/12 budget to parliament framed around its Fiscal Adjustment Roadmap (FAR). The goal of the budget is to reduce the overall fiscal deficit to 7.5 percent of GDP. This significant fiscal adjustment will be achieved through tax increases as well as expenditure cuts. On the revenue front, the fuel levy and taxes on alcohol and tobacco have been increased, while the sales tax will be extended to a number of economic activities, including mobile phone calls. Legislation is currently before parliament to introduce a value added tax by April 2012. The Swaziland Revenue Authority has become operational. The authorities have committed to cutting the wage bill by 5 percent (E240 million) in FY 2011/12. Staff recommended that these cuts be focused on the higher pay scales so as to protect the poorest civil servants.. As a first step, the authorities have cut salaries of cabinet ministers by 10 percent and are negotiating with parliamentarians and trade unions to achieve the targeted reduction. Other nonpriority current and capital expenditure have also been significantly reduced, while expenditure on education and health has been protected. The government has also announced its intentions to privatize Swazi Bank and launch an international tender for a second mobile phone operator license by end-2011.

The authorities have requested that their FAR be monitored by a Staff-Monitored Program (SMP). The main objective of the program is to restore fiscal sustainability by reducing the deficit to below 3 percent of GDP by 2014/15. This should stabilize the debt-to-GDP ratio around 35 percent, while maintaing the gross official reserves of the central bank sufficient to provide full coverage of reserve money plus 50 percent of domestic currency deposits. The SMP aims also to strengthen public finance management. Finally, the program will protect priority expenditure in education and health in order to continue to make progress toward the United Nations Millenium Development Goals and the fight against HIV/AIDS.

The main risks to the program stem from a lack of political and social consensus on the reform agenda, limited administrative capacity, and uncertainties regarding SACU revenue. These risks have been mitigated in the program by a set of prior acitons, the safeguarding of propoor spending, and improved transparency. Additional risks to the program could surface from a change in SACU revenue sharing formula, currently under consideration by SACU members. 


\section{ReCEnt EConomic DeVelopments AND Short-Term OUtLook}

1. The Swaziland economy continues to suffer from the global economic crisis and an overvalued real exchange rate. Real GDP growth recovered to an estimated 2 percent in 2010, on the back of a moderate recovery in South Africa. Swaziland, however, continues to be the worst performer in the SACU region, partly reflecting an overvalued exchange rate and the heavy toll of HIV/AIDS on human capital (Figure 1). The large fiscal adjustment in 2011 is projected to dampen real GDP growth to about 0.5 percent. Inflation moderated in 2010, notwithstanding the increase in fuel prices in November 2010. It is, however, expected to rise to about 8 percent in 2011, as higher taxes and the increase in international food and fuel prices pass through to higher consumer prices. The real effective exchange rate appreciated by 5.1 percent in the twelve months to December 2010 (Table 1).

2. The fiscal crisis continues to deepen. Following a large decline in SACU imports in 2009, transfers from the SACU revenue pool to Swaziland fell by 11 percent of GDP during the 2010/11 fiscal year. ${ }^{1}$ In parallel, the wage bill-one of the largest in Sub-Saharan Africa-increased further, following an unbudgeted 4.5 percent wage increase granted to civil servants in 2010 . While capital expenditure commitments have been halved in recent months to offset the impact of lower SACU revenue, this was partly reversed by a supplementary budget in November 2010 to regularize capital expenditure overruns of about E350 million for a new airport project. As a result, the fiscal deficit (commitment basis) is expected to nearly double to about 13 percent of GDP in 2010/11, compared with 7.1 percent in the previous fiscal year. The government has been financing the deficit by issuing government bonds, drawing down its deposits at the central bank, and incurring domestic payment arrears on all expenditure items except for wages and utilities. The latest issuance of a 7-year bond in January 2011 for E750 million was heavily undersubscribed, which led the CBS to provide an emergency credit line of E620 million (2.3 percent of GDP) to the government to enable wage payments to civil servants in February 2011.

3. The fiscal crisis is starting to affect external stability (Figure 2 and 3 ). With an overvalued real exchange rate, weak export growth, and the decline in SACU transfers, the external current account balance widened to about 181/2 percent of GDP in 2010. In addition, foreign direct investment and other financial flows remain stagnant. As a result, gross official reserves have been steadily declining since January 2010 and covered only about 250 percent of reserve money and 21/2 months of imports at end-February 2011.

4. The large current account deficit has led to a contraction in reserve money and a subsequent deflationary impact. In addition, notwithstanding a significant reduction in policy rates throughout 2010, in line with the policy of the South African Reserve Bank, credit to the private sector increased only moderately, suggesting conservative lending policies by the banking system (Figure 4). Monetary aggregates expanded in line with nominal GDP.

\footnotetext{
${ }^{1}$ The fiscal year starts on April 1 and ends on March 31 of the following year.
} 
Figure 1. Recent Economic Developments and Regional Comparison

Growth has slowed down with a continuing downward trend...

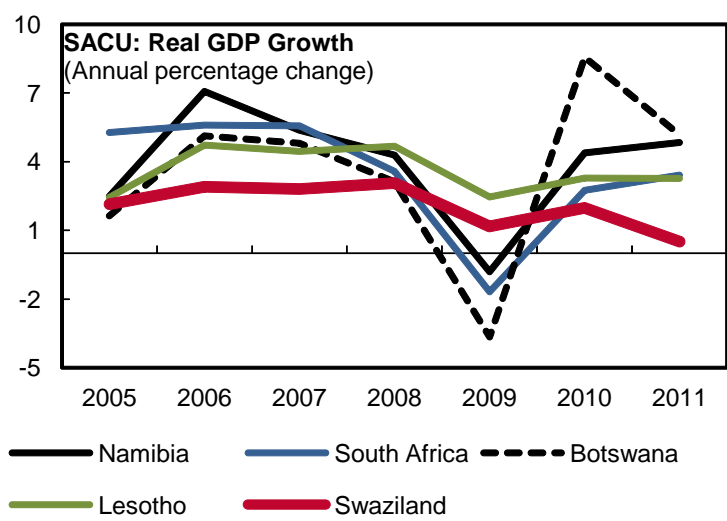

The poverty headcount remains high...

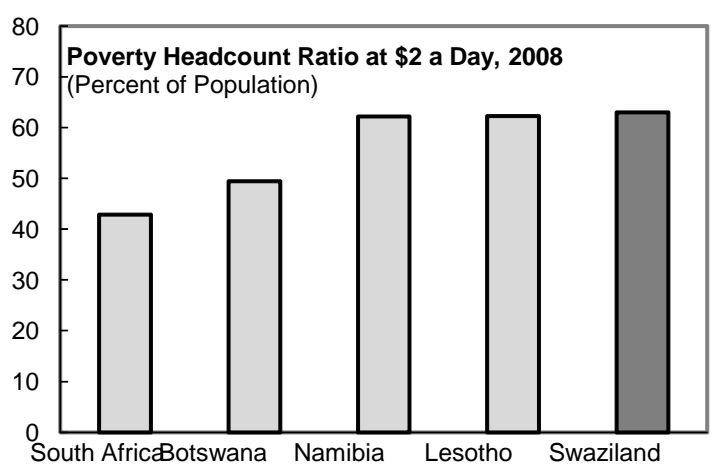

At present, inflation remains moderate in line with South Africa...

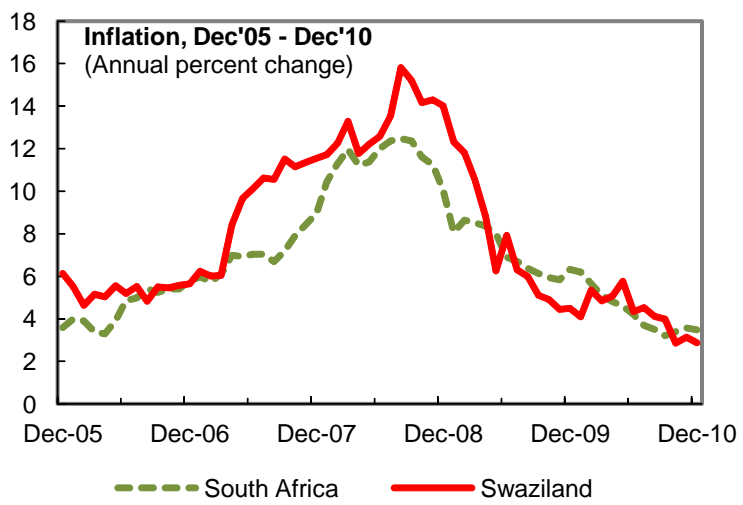

...and the growth performance remains lower than that of other SACU countries.

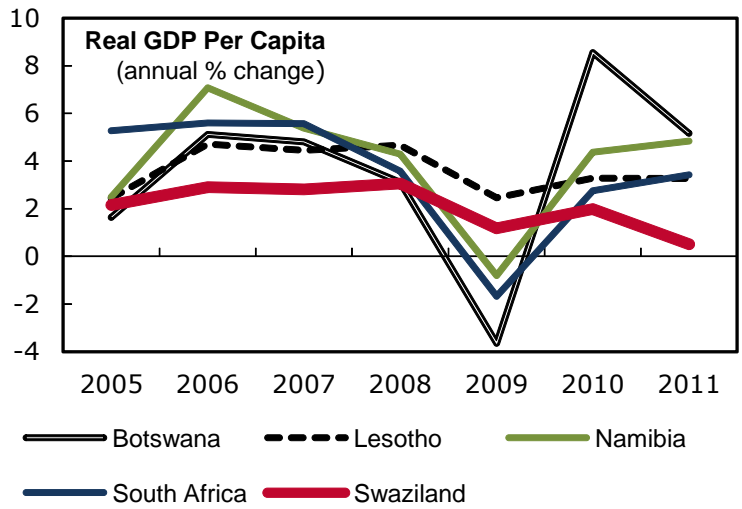

... with the highest incidence of HIV/AIDS in the world.

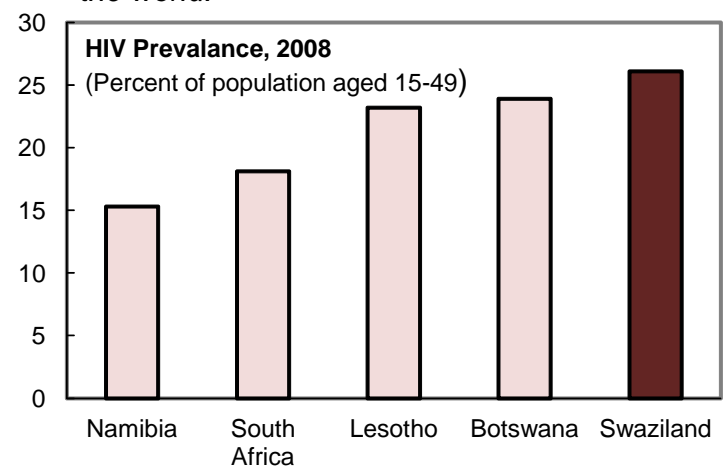

... but food prices are on the rise.

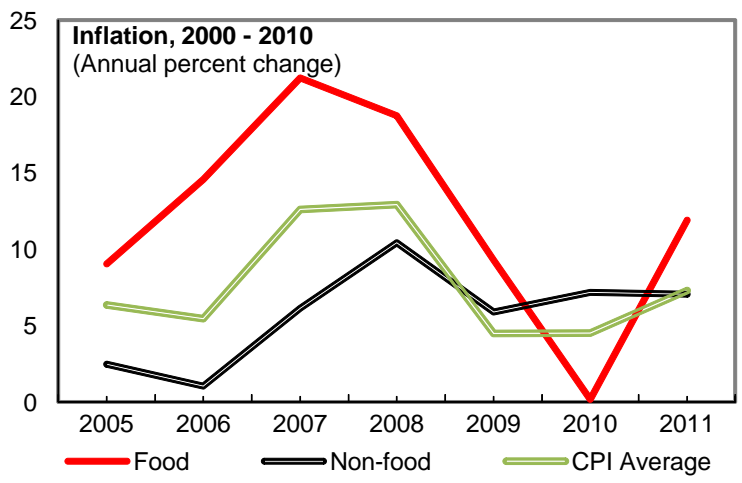

Source: Country authorities; World Development Indicators; and Fund staff estimates. 
Figure 2. Fiscal Balance, Current Account Balance, and Gross International Reserves, 2006-11

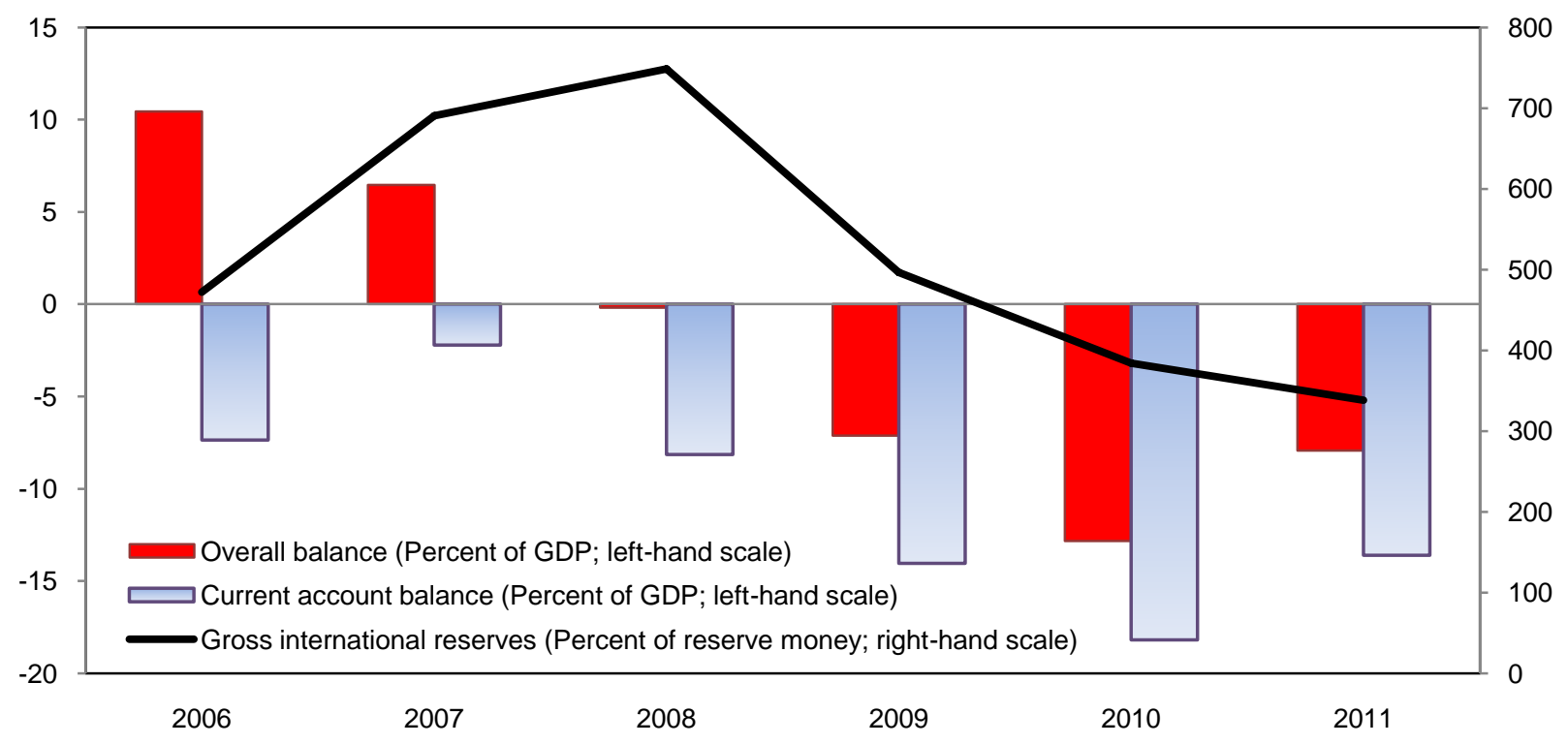

Source: Authorities and Fund staff estimates and projections. 
Figure 3. The Fiscal Crisis is Unfolding into an External Crisis

The REER has appreciated considerably...

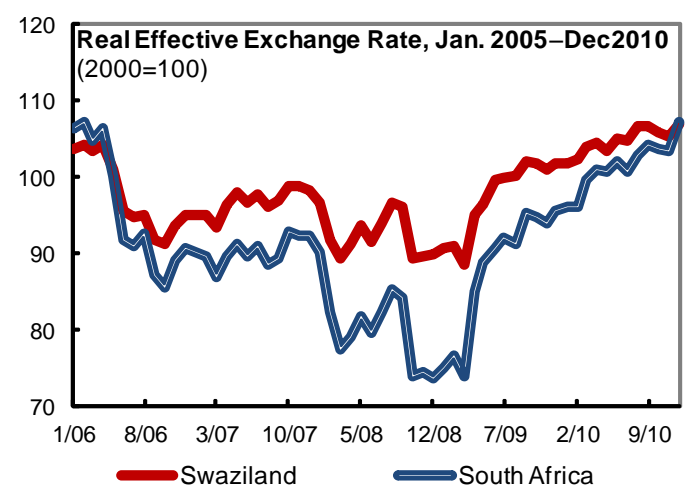

... contributing to a deterioration of the trade balance.

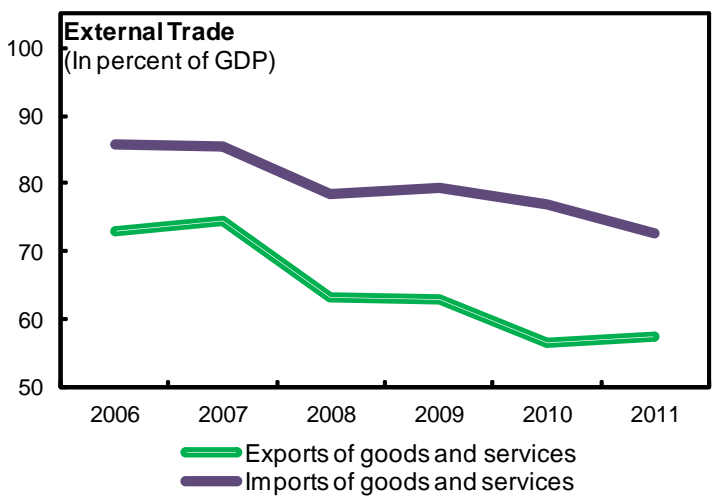

As the overall fiscal balance turned into a large deficit... ...the external current account widened correspondingly...
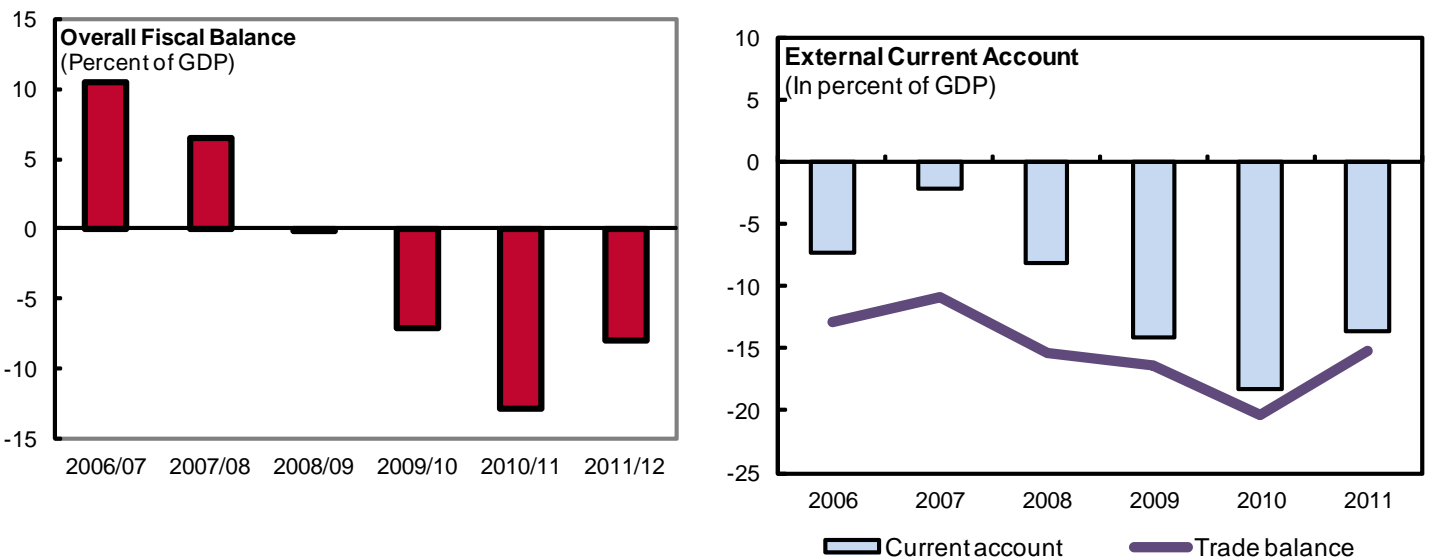

Central Bank's net foreign assets also dropped in glight of the decline in SACU transfers ...

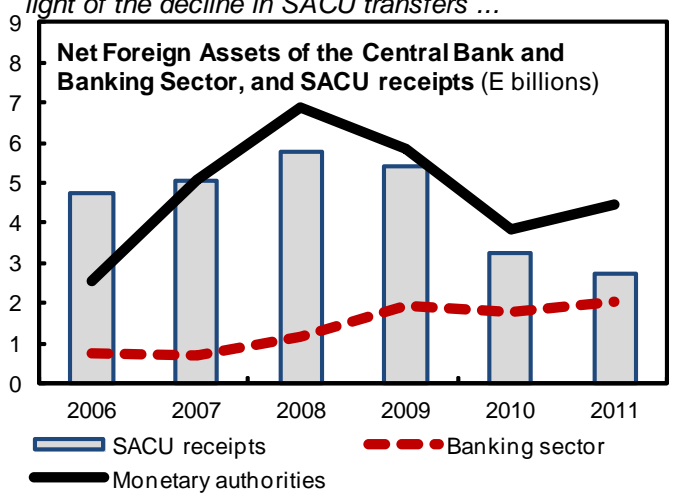

... leading to lower reserve coverage of broad money

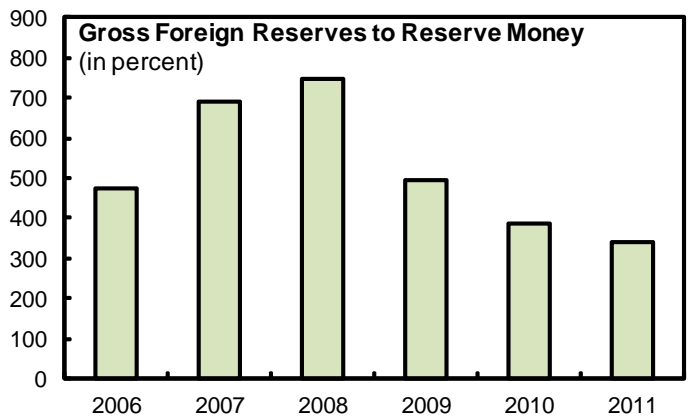

Source: Country Authorities, Information Notice System, and Fund staff estimates 
Figure 4 Policy Rate of the Central Bank of Swaziland and Private Sector Developments

Notwithstanding continued monetary easing...

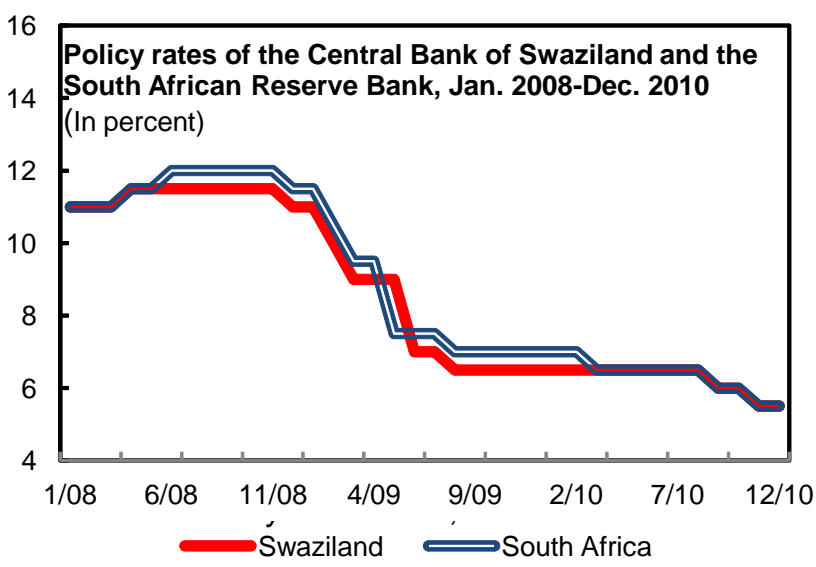

Source: Country Authorities and Fund staff estimates. ...monetary expansion has been moderate

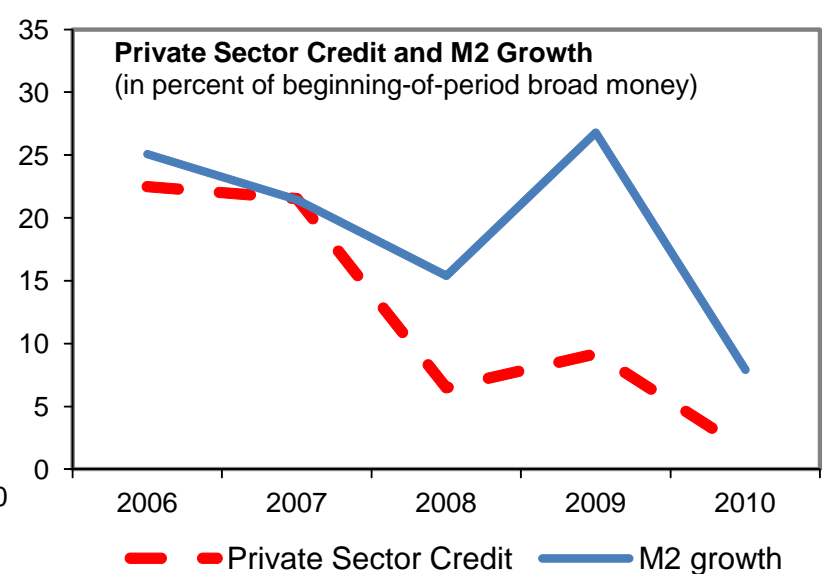

5. Notwithstanding the fiscal crisis, banks continue to remain well-capitalized and profitable (Figure 5). Capital adequacy has fallen to about 12 percent in 2010, while the share of non-performing loans has declined somewhat to 8 percent. However, several banks are highly exposed directly to the government, and indirectly to civil servants. Further increases in domestic arrears could lead to a significant jump in non-performing loans. At the same time, non-bank financial institutions and their lending activities have been growing rapidly.

Figure 5. The Banking sector is weathering well the financial crisis

Banks remain well-capitalized,non-performing loans are declining, and bank profitability remains high.
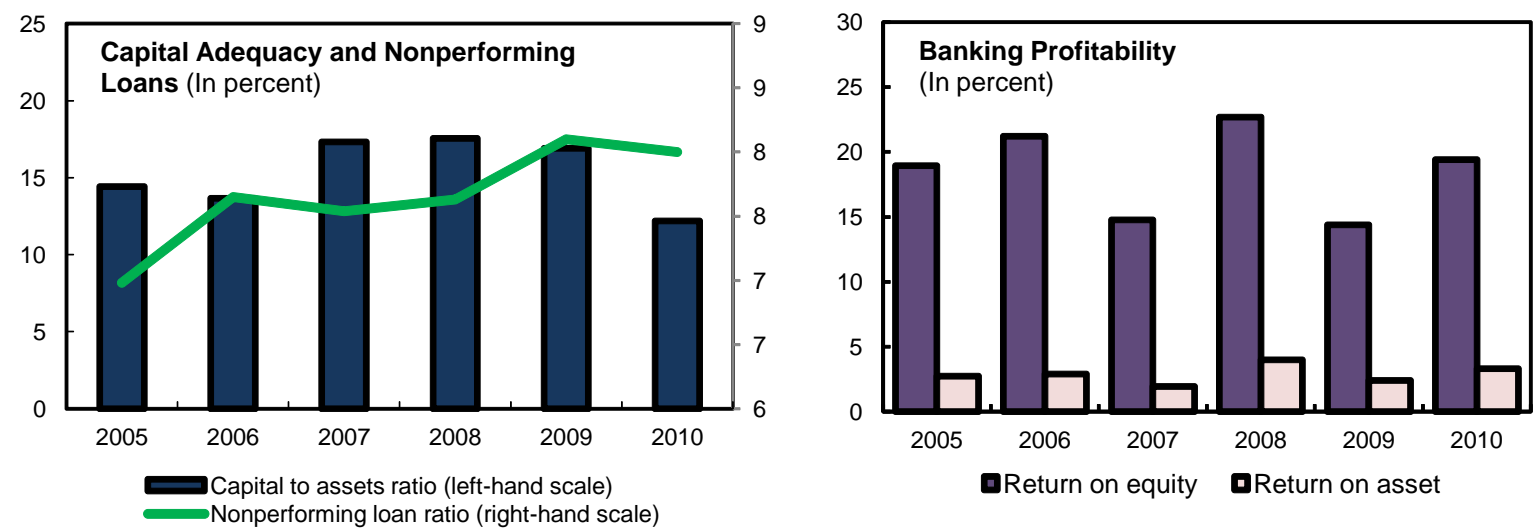

Source: Country authorities and Fund staff estimates.

6. Poverty continued to decline over the last decade, albeit at a slow pace. According to the Swaziland Household Income and Expenditure Survey published in February 2011, the headline poverty count decreased by 6 percentage points to 63 percent in the nine years to 2009/10. Poverty remains mainly a rural phenomenon in Swaziland, with 89 percent of the poor living in rural areas. 


\section{The Staff-Monitored Program}

7. The authorities' Staff-Monitored Program (SMP) aims to build a strong track record of fiscal consolidation and structural reform to support the authorities' possible request for a formal Fund arrangement in late 2011. The SMP is driven by four main objectives: (i) reduce the deficit to below 3 percent of GDP by 2014/15, which will limit the debt-to-GDP ratio to around 35 percent; (ii) maintain the gross international reserves at a level sufficient to provide full coverage of reserve money plus 50 percent on average of domestic currency deposits in order to safeguard external sustainability; (iii) strengthen public finance management; and (iv) protect priority spending in order to continue to make progress towards achieving the United Nations Millennium Development Goals, including the fight against HIV/AIDS (Memorandum of Economic and Financial Policies (MEFP), 95). The SMP is in line with the government's Poverty Reduction Strategy and Action Program (PRSAP).

8. The medium term outlook remains broadly unchanged from the one presented in the staff report for the 2010 Article IV consultation. Only moderate growth is expected, averaging about 2 percent over the medium term. Inflation is projected to average 5 percent over the medium term. The external current account deficit is projected to decline in line with the fiscal adjustment path. Accordingly, the gross international reserve position would strengthen to about 5 months of import cover, while remaining above the full coverage of reserve money plus 50 percent of domestic currency deposits.

\section{A. Fiscal Policy}

9. The 2011/12 budget promises to make significant progress in fiscal adjustment while safeguarding priority expenditures (Box 1). The draft budget presented to parliament on February 18, 2011 projects an increase in tax revenue of 23 percent, supported by optimistic assumptions on improvements in tax collections by the newly-established Swaziland Revenue Authority. In order to stick to more prudent assumptions, the authorities agreed to lower revenue projections in the Staff-Monitored Program. In addition, the fuel levy has been increased twice (10 and 15 cents per liter in February and March 2011, respectively; prior action), the sales tax on alcohol and cigarette (from 25 to 30 percent), and the removal of sales tax exemptions on various products and services such as mobile phone services (MEFP, \14). On the expenditure side, the adjustment will be mainly in the wage bill (see below). Furthermore, expenditures on goods and services will be reduced by 20 percent and allocations for current transfers and non-priority investment spending will be trimmed down. ${ }^{2}$ These revenue and expenditure measures will make it possible for the government to reduce the overall fiscal deficit to about 8 percent of GDP on a commitment basis. In addition, the government has committed to repaying all outstanding arrears by end-March 2012, implying that the fiscal deficit on a cash basis will rise to about 12 percent of

\footnotetext{
${ }^{2}$ The increase in subsidies in FY 2011/12 is explained by one-off transfers to the Swaziland Revenue Authority and the Civil Aviation Authority, which are expected to be self-financed starting in FY 2012/13.
} 


\section{Box 1. Fiscal Measures in the 2011/12 Budget}

The 2011/12 budget is predicated on a deficit of 7.9 percent of GDP (E 2.4 billion). This deficit is expected to be achieved through a set of revenue and expenditure measures. The table below summarizes the main changes compared to the 2010/11 budget.

On the revenue side, measures essentially focus on tax rates increases and removal of tax exemptions. Main tax rate adjustment will consist in a harmonization with rates applied in the region, notably in South Africa (fuel taxes, gambling taxes). Additionally, exemptions will be removed, notably on mobile phone communications, which will be taxed at the regular sales tax rate of 14 percent. Over the medium-term, a mild recovery in SACU transfers is also expected to generate additional revenue of 2 percent of GDP, which would occur once Swaziland has paid the amount due to the SACU pool.

On the expenditure side, the main adjustment will come from the wage bill. In nominal terms the wage bill goes from E4.9 billion to E4.2 billion, because of (i) a nominal wage bill cut of about E240 million, while protecting the poorest civil servants (ii) the end of the provision of E400 million for the EVERS program, which was paid in 2010/11 and is no longer due, and the remaining part (about E60 million) from cuts in other allocations. Overall these cuts, given the GDP increase for 2011/12, generate 3.6 percent of savings, while education and health expenditure is being protected. The continued decline in the subsequent years would largely come from the implementation of the EVERS program, together with a wage and hiring freeze. In addition, the authorities plan to limit the growth of capital spending and transfers, except, for the latter, a one-off increase, largely coming from settingup the new Swaziland Revenue Administration. Further savings on goods and services will complement the measures on the wage bill.

Text Table 1. Swaziland: Summary of Measures for FY2011/12

\begin{tabular}{|c|c|c|}
\hline Measures & E millions & $\%$ GDP Comments \\
\hline Revenue measures (+ = increase) & 366 & 1.2 \\
\hline Fuel tax & 88 & $\begin{array}{l}0.3+25 \text { cents as of December } 2010,+10 \text { cents } \\
\text { as of Februay, }+15 \text { cents as of March } 2011\end{array}$ \\
\hline Sales tax & 170 & 0.6 \\
\hline Mobile phone communications & 67 & 0.2 Introduction of a 14 percent sales tax \\
\hline Tobacco & 5 & $0.0 \begin{array}{l}\text { Increased from } 25 \text { to } 30 \text { percent on imported } \\
\text { tobacco }\end{array}$ \\
\hline Alcohool & 5 & $\begin{array}{l}0.0 \begin{array}{l}\text { Increased from } 25 \text { to } 30 \text { percent on imported } \\
\text { alcohool }\end{array}\end{array}$ \\
\hline Removal of tax exemptions & 57 & 0.2 \\
\hline Gaming tax & 80 & 0.3 Gaming tax increased from 4.5 to 15 percent \\
\hline Improvement in income tax compliance & 29 & 0.1 \\
\hline Expenditure measures (+ = increase) & -404 & -1.4 \\
\hline Goods and services & -198 & -0.7 \\
\hline Transfers and subsidies & 453 & 1.5 \\
\hline \multicolumn{3}{|l|}{ Of which: } \\
\hline Set-up of the revenue administration (SRA) & 300 & 1.0 \\
\hline Wage bill & -692 & -2.3 \\
\hline EVERS contribution & -400 & -1.3 \\
\hline Wages & -240 & -0.8 \\
\hline Allocations & -52 & -0.2 \\
\hline Capital spending & 33 & 0.1 \\
\hline Deficit in $2011 / 12$ & $-2,373$ & -7.9 \\
\hline \multicolumn{3}{|l|}{$\begin{array}{l}\text { Memorandum items: } \\
\text { Nominal GDP in 2011/12 }\end{array}$} \\
\hline Nominal GDP in 2011/12 & 29,909 & 100.0 \\
\hline
\end{tabular}


GDP. Given the ongoing financing constraints, most of the arrears repayment will take place in the latter part of FY 2011/12, once external financing becomes available.

10. The government is taking ambitious measures to cut the wage bill in FY 2011/12 (structural benchmark at end-May 2011). The wage bill will be cut by E240 million (3/4 percent of GDP) in nominal terms relative to the $2010 / 11$ estimated outturn through a graduated wage cut affecting mainly the top-paid civil servants. While negotiations on the wage cut are still ongoing with parliamentarians and trade unions, the government has already implemented a 10 percent wage cut for cabinet ministers effective April 1, 2011. The government will also implement the Enhanced Voluntary Early Retirement Separation (EVERS) program with the goal of eliminating 7,000 civil service jobs by March 2012 (MEFP, I15). The government had already provisioned a one-off expense for the EVERS program of E400 million (1.3 percent of GDP), which will carry over to FY 2011/12. In addition, the government has implemented a wage and hiring freeze, eliminated a number of vacant positions, and stopped notch increases, which are expected to generate E55 million in savings (0.2 percent of GDP). Overall, these measures are expected to reduce the wage bill by about E700 million (2.3 percent of GDP) in FY 2011/12. The resulting fiscal space will be used by the authorities to support economic growth and poverty reduction, including by curbing the spread of HIVIAIDS, improving education, and helping to achieve the Government's objective of halving the poverty rate by 2015 (MEFP, \19).

11. The projected financing gap for $2011 / 2012$ is expected to be closed with additional external budget support and privatization proceeds. The expected financing gap will be narrowed with the anticipated financial assistance from the African Development Bank, the World Bank, bilateral donors, and a possible Fund arrangement in late 2011. Additional financing is envisaged from the international tender of a second international mobile phone license and the privatization of Swazi Bank for which initial steps have already been taken (MEFP, I18). The mission has also advised the authorities to publish a schedule of bond issuances to facilitate the participation of banks, insurance companies and pension funds. ${ }^{3}$

12. Improvements in revenue administration by the Swaziland Revenue Authority (SRA) will strengthen revenue collections. The SRA became fully operational on January 1, 2011. Following the recommendations of the FAD technical assistance in January 2011, the SRA is elaborating a taxpayer compliance strategy, based on (i) improvements in the information system (new IT equipments, development of a tax registry, and a unique taxpayer identification number), and (ii) a focus on a "full service" Large Taxpayer Unit. The revenue collection effort will be further strengthened with the implementation of the Automated System for Customs Data (ASYCUDA) in March 2011. The SRA is also making significant progress in the preparations for the implementation of a VAT in April 2012, including by launching a tender for the implementation of the new Integrated Tax Administration Software. These tax administration efforts, together with additional tax measures and the elimination of tax exemptions, are projected to increase tax

\footnotetext{
${ }^{3}$ The large increase in nonbank financing in FY 2011/12 reflects the larger expected participation of insurance companies and pension funds in the government's bond auctions.
} 
revenue collections (excluding SACU receipts) by about 3 percent of GDP over the medium term. In addition, SACU transfers are expected to recover by over 2 percent of GDP over the medium term, absent a change in the SACU revenue-sharing formula. As a result, total revenue is projected to reach 32 percent of GDP by 2016/17, compared with 24.5 percent in 2010/11.

13. Following a second FAD technical assistance mission in February 2011, the authorities' public finance management (PFM) reforms will be based on the following four pillars: (i) Budget reporting and transparency: A cash flow monitoring committee has been established with the responsibilities to project and monitor all cash flows as well as to calculate the available cash balance. The Ministry of Finance website is under development, and the authorities will post on it the budget outlook, annual transparency reports, and the General Auditor reports on the budget starting April 1, 2011; (ii) Expenditure controls: All expenditures will be authorized centrally by the MOF. In this context, the Policy and Budgeting Committee, which divided up control of the budget between three ministries in the past, has been eliminated (prior action). Commitment registers, commitment plans and forecasts of resultant expenditure payments will be introduced; (iii) Budget process: The new Public Finance Management Act, expected to be submitted to Parliament by end-June, 2011, lays out the functions, duties and responsibilities of all budgetary institutions in the implementation of the budget. Additionally, the authorities will commence preparation of the budget earlier in the calendar year, a macro-fiscal unit will be created within the MOF and the coordination capacity of the Budget Directorate will be strengthened. The MOF will also adopt a more output- and performance-based framework for budget formulation; (iv) Overall PFM reform strategy: A high level steering committee will be established to design a Public Financial Management Reform Strategy which will facilitate the implementation of the FAR.

\section{B. Monetary and Financial Policy}

14. Monetary policy aims at preserving a level of gross official reserves consistent with maintaining the credibility of the exchange rate parity of the lilangeni with the South African Rand. Accordingly, the policy rates will continue to follow those of the South African Reserve Bank (SARB). The central bank will continue to ensure external stability by keeping to an adequate level of gross official reserves in months of import cover and as a ratio to reserve money (MEFP, \22).

15. While banks are well capitalized, profitable and liquid, non-bank financial institutions (NBFIs) present some vulnerability. The authorities intend to take further measures to strengthen the regulation of non-bank financial institutions and address weaknesses in the supervision of Savings and Credit Cooperatives as well as other NBFI, including pension funds. These measures include the passage of the securities bill in December 2010 and the creation of the Financial Services Regulatory Authority (FSRA) expected to be operational by end-April 2011. These measures should establish a comprehensive regulatory framework for the nonbank financial supervision. The authorities remain vigilant about possible spillover effects of the fiscal crisis onto the financial system. 


\section{Structural Reforms}

16. The government has resumed its 2004 privatization program, with the goal of attracting additional foreign direct investment into Swaziland and financing the budget. This will commence with the privatization of the sate-owned Swazi Bank expected by end-2011, with technical assistance from donors, and the launch of an international tender for a second mobile phone license. In addition, the government plans to transform the Central Transportation Administration into a state-owned enterprise with an independent budget audited annually, with a view to privatizing the company at a later stage.

17. The authorities further plan to take measures to reduce the cost of doing business in Swaziland and improve the business climate. The envisaged public sector wage cuts are likely to put downward pressure on private sector wages, reduce unit labor costs, and thus improve competitiveness. The government is also considering reforms to facilitate the development of the private sector by adopting simpler rules, regulations and procedures to start, operate, and expand a business. The Companies Act passed in 2010 is expected to streamline licensing procedures considerably. The authorities are exploring additional incentives which would attract domestic investment as well as FDI, and are also studying ways to facilitate trade with neighboring countries. In addition, a growth diagnostic study and an economic diversification study will be conducted with assistance from the World Bank and the African Development Bank, respectively, to facilitate the Swaziland Investment Promotion Authority (SIPA)'s drive to promote FDI.

\section{OBJECTIVES AND RISKS TO THE IMPLEMENTATION OF THE SMP}

18. The main objective of the SMP is to establish a strong track record for a possible request for a formal Fund arrangement in late 2011. The SMP prepares for upper-credit tranche conditionality, in so far as the authorities will have implemented large revenue measures and a significant cut in recurrent expenditures to reduce the overall fiscal deficit by about 5 percent of GDP in FY 2011/12. The SMP is also going to make progress towards reducing domestic arrears and is expected to give a signal for donors to provide external budgetary support. On structural reforms, the SMP will put in place changes to legislation to improve public financial management, to transform the Central Transport Administration into a proper public enterprise with budget reporting requirements and oversight by the Ministry of Finance, changes in tax laws in line with Fund staff recommendations, and the submission to parliament of the VAT legislation. These measures should all contribute to the authorities' future adjustment efforts.

19. The SMP will be monitored through quantitative targets and structural benchmarks (MEFP, I31). The quantitative targets include ceilings on the total financing requirement of the central government, the net domestic assets of the central bank, and the stock of domestic and external arrears. They also include floors on the central government social expenditure and the stock of net international reserves of the central bank. The structural benchmarks cover key macrocritical measures. The SMP will have two assessments, one based on end-March 2011 targets and the second one based on end-June 2011 targets. 
20. The main risks to the program stem from lack of political and social cohesion around the need for fiscal consolidation, and limited implementation capacity. These risks could result in a slower speed of fiscal adjustment, and accordingly a higher debt to GDP ratio over the medium term. These risks have been mitigated in the program by a set of prior acitons aimed at frontloading the fiscal adjustment while safeguarding pro-poor spending and improving transparency. In addition, the approval of the first assessment of the SMP will be conditional on implementing measures sufficient to achieve the targeted reduction in the wage bill by E240 million. Additional risks to the program could surface from a change in the SACU revenue sharing formula, currently being debated by SACU members. Such changes may require a redesign of the program to take into account revised projections for SACU revenue and the potential need for further fiscal adjustment. Finally, the implementation of recommendations of the forthcoming safeguards assessment mission during the SMP will provide additional assurances that the appropriate controls are in place at the central bank for a possible Fund arrangement.

\section{StAFF Appraisal}

21. The authorities' program promises to make significant progress towards the necessary fiscal consolidation in Swaziland. The 2011/12 budget demonstrates the resolve to address the fiscal crisis head on with a series of difficult revenue and expenditure measures that will permanently reduce Swaziland's dependence on SACU revenue. While the fiscal adjustment will necessarily have a negative impact on growth in 2011, the authorities' decision to relaunch the 2004 privatization program and improve the business climate will set the stage for a resumption of private-sector led growth over the long term.

22. The 2011/12 budget is appropriately ambitious, notwithstanding optmistic revenue assumptions. The goal to reduce the fiscal deficit to less than 8 percent of GDP is commendable. However, to achieve this goal, the authorities would be advised to rely less on improvements in tax administration, which may not materialize, and more on permanent expenditure cuts. In this context, the authorities' decision to move forward with a graduated wage cut is commendable, despite strong political opposition from the trade unions. The wage cut will not only alleviate the fiscal pressure on the budget; it will also strengthen competitiveness over the medium term. The authorities should press ahead to conclude negotiations with parliamentarians and trade unions at the earliest possible opportunity in order to secure the wage bill reduction, while protecting the lowest paid civil servants. The authorities are also encouraged to start their EVERS program as soon as possible, so as to secure additional savings on the wage bill over the medium term. The authorities should use the fiscal space created by these cuts to increase spending on education and health, given the need to curb the spread of HIV/AIDS, improve education, and make progress towards halving the poverty rate by 2015 .

23. The financing of the budget for the first half of 2011 remains a significant challenge. Commercial banks' willingness to continue to finance the large government financing needs depends critically on the implementation of the government's fiscal adjustment roadmap and the transparency of fiscal operations. The authorities' intention to publish fiscal data on the MOF website on a regular basis will help in this regard. The government and the CBS are also encouraged to announce a yearly schedule of bond auctions with different maturities, which could 
help banks, pension funds, and insurance companies to strengthen their participation through appropriate treasury management.

24. The staff-monitored program is also supported by measures to strengthen privatesector led growth. The relaunch of the 2004 privatization program is likely to bring in additional foreign direct investment and provide much-needed financing to the budget. The authorities' measures to lower the cost of doing business may provide additional incentives for private investment over the medium term.

25. The staff-monitored program provides a comprehensive approach to deal with current fiscal crisis. While there are significant risks to program implementation, those have been mitigated through a series of prior actions. If implemented satisfactorily, the program would establish a strong track record for the authorities' possible request for a formal Fund arrangement in late 2011. 
Table 1. Swaziland: Selected Economic Indicators, 2009-16

\begin{tabular}{|c|c|c|c|c|c|c|c|c|}
\hline & 2009 & 2010 & 2011 & 2012 & 2013 & 2014 & 2015 & 2016 \\
\hline & & & \multicolumn{6}{|c|}{ Projections } \\
\hline & \multirow{2}{*}{\multicolumn{8}{|c|}{ (percentage changes; unless otherwise indicated) }} \\
\hline \multicolumn{3}{|l|}{ National account and prices ${ }^{1}$} & & & & & & \\
\hline GDP at constant prices & 1.2 & 2.0 & 0.5 & 1.5 & 2.5 & 2.5 & 2.5 & 2.5 \\
\hline GDP per capita at constant prices & 1.4 & 2.4 & 0.9 & 1.9 & 2.9 & 2.9 & 2.9 & 2.9 \\
\hline GDP deflator & 5.4 & 6.2 & 7.8 & 6.3 & 3.3 & 4.5 & 4.1 & 4.1 \\
\hline \multicolumn{9}{|l|}{ GDP at market prices } \\
\hline (Emalangeni millions) & 24,995 & 27,064 & 29,333 & 31,637 & 33,498 & 35,882 & 38,267 & 40,828 \\
\hline \multicolumn{9}{|l|}{ Consumer prices (average) } \\
\hline Headline & 7.5 & 4.5 & 7.9 & 6.1 & 5.3 & 5.2 & 4.8 & 4.5 \\
\hline Underlying (excluding food) & 5.9 & 7.2 & 6.8 & 6.1 & 5.3 & 5.2 & 4.8 & 4.5 \\
\hline \multicolumn{9}{|l|}{ External sector } \\
\hline \multicolumn{9}{|l|}{ Average exchange rate } \\
\hline (local currency per US\$) & 8.4 & 7.6 & $\ldots$ & $\ldots$ & $\ldots$ & $\ldots$ & $\ldots$ & $\ldots$ \\
\hline Nominal exchange rate change $\left(-={\text { depreciation })^{2}}^{2}\right.$ & 12.7 & 5.4 & $\ldots$ & $\ldots$ & $\ldots$ & $\ldots$ & $\ldots$ & $\ldots$ \\
\hline Real effective exchange rate $\left(-=\right.$ depreciation $^{2}$ & 13.2 & 5.1 & $\ldots$ & $\ldots$ & $\ldots$ & $\ldots$ & $\ldots$ & $\ldots$ \\
\hline \multicolumn{9}{|l|}{ Gross international reserves } \\
\hline (months of imports) & 3.9 & 2.6 & 2.9 & 3.4 & 4.1 & 4.9 & 5.0 & 4.9 \\
\hline (percent of reserve money) & 496.5 & 383.8 & 338.1 & 264.4 & 225.6 & 204.0 & 207.0 & 204.8 \\
\hline \multicolumn{9}{|l|}{ Money and credit ${ }^{3}$} \\
\hline Domestic credit to the private sector & 10.1 & 2.0 & 8.4 & 7.8 & 5.9 & 7.1 & 6.6 & 6.7 \\
\hline Reserve money & 38.3 & -10.2 & 31.2 & 50.8 & 48.2 & 39.7 & 6.6 & 6.7 \\
\hline M2 & 26.8 & 7.9 & 8.4 & 7.9 & 5.9 & 7.1 & 6.6 & 6.7 \\
\hline \multirow[t]{2}{*}{ Interest rate (percent) ${ }^{4}$} & 7.8 & 5.7 & $\ldots$ & $\ldots$ & $\ldots$ & $\ldots$ & $\ldots$ & $\ldots$ \\
\hline & \multicolumn{8}{|c|}{ (percent of GDP) } \\
\hline \multicolumn{9}{|l|}{ National accounts } \\
\hline Gross capital formation & 14.4 & 12.4 & 11.6 & 12.6 & 13.3 & 13.5 & 14.0 & 14.0 \\
\hline Government & 8.9 & 7.1 & 6.3 & 7.2 & 7.9 & 8.1 & 8.6 & 8.6 \\
\hline Private & 5.5 & 5.3 & 5.3 & 5.4 & 5.4 & 5.4 & 5.4 & 5.4 \\
\hline National savings & 0.3 & -5.8 & -2.0 & 2.1 & 5.4 & 8.3 & 9.0 & 9.0 \\
\hline Government & 3.9 & -3.4 & -1.7 & 2.8 & 5.8 & 7.1 & 7.9 & 7.9 \\
\hline Private & -3.6 & -2.4 & -0.3 & -0.7 & -0.4 & 1.2 & 1.1 & 1.1 \\
\hline \multicolumn{9}{|l|}{ External sector } \\
\hline \multicolumn{9}{|l|}{ Current account balance } \\
\hline (including official grants) & -14.0 & -18.2 & -13.6 & -10.5 & -7.8 & -5.2 & -5.0 & -5.0 \\
\hline (excluding official grants) & -18.1 & -18.6 & -12.9 & -9.6 & -7.5 & -5.2 & -5.2 & -5.2 \\
\hline External public debt & 12.0 & 12.1 & 18.0 & 23.3 & 26.5 & 28.3 & 29.8 & 30.4 \\
\hline \multicolumn{9}{|l|}{ Central government fiscal operations ${ }^{5}$} \\
\hline Overall balance (commitment basis) & -7.1 & -12.8 & -7.9 & -5.0 & -2.9 & -2.3 & -2.2 & -2.2 \\
\hline (excluding grants) & -7.6 & -13.9 & -8.8 & -5.7 & -3.6 & -3.0 & -2.9 & -2.9 \\
\hline Revenue & 35.7 & 24.5 & 25.8 & 27.1 & 29.4 & 30.5 & 31.6 & 32.1 \\
\hline Grants & 0.5 & 1.1 & 0.9 & 0.7 & 0.7 & 0.7 & 0.7 & 0.7 \\
\hline Total expenditure and net lending & 43.3 & 38.3 & 34.6 & 32.8 & 33.0 & 33.5 & 34.5 & 35.0 \\
\hline Public debt, gross & 12.6 & 20.6 & 26.8 & 30.6 & 32.9 & 34.1 & 35.2 & 35.2 \\
\hline Public debt, net & -3.5 & 12.4 & 19.6 & 23.9 & 26.6 & 28.2 & 29.7 & 30.0 \\
\hline \multicolumn{9}{|c|}{ Sources: Swazi authorities; and Fund staff estimates and projections. } \\
\hline \multicolumn{9}{|c|}{${ }^{1}$ The official GDP numbers from 1994 to 2006 were significantly revised in 2007, and recently in 2008.} \\
\hline \multicolumn{9}{|c|}{${ }^{2}$ IMF Information Notice System trade-weighted; end of period. } \\
\hline \multicolumn{9}{|c|}{${ }^{3}$ Percent of beginning-of-period broad money; end-September for 2009.} \\
\hline${ }^{4} 12$-month time deposits rate. & & & & & & & & \\
\hline & & & & & & & & \\
\hline
\end{tabular}


Table 2. Swaziland: Fiscal Operations of the Central Government, 2009/10-16/17 ${ }^{1}$

(Emalangeni millions)

\begin{tabular}{|c|c|c|c|c|c|c|c|c|}
\hline & $2009 / 10$ & $2010 / 11$ & $\begin{array}{r}2011 / 12 \\
\text { Prog. }\end{array}$ & $2012 / 13$ & $2013 / 14$ & $2014 / 15$ & $2015 / 16$ & $2016 / 17$ \\
\hline & & & \multicolumn{6}{|c|}{ Projections } \\
\hline Total revenue and grants & 9,222 & 7,053 & 7,980 & 8,927 & 10,269 & 11,379 & 12,593 & 13,624 \\
\hline Revenue & 9,102 & 6,757 & 7,715 & 8,702 & 10,030 & 11,124 & 12,312 & 13,343 \\
\hline Tax revenue & 8,732 & 6,584 & 7,528 & 8,501 & 9,816 & 10,895 & 12,068 & 13,083 \\
\hline Taxes on income, profits, and capital gains & 2,326 & 2,462 & 2,677 & 2,880 & 3,093 & 3,455 & 3,879 & 4,347 \\
\hline Taxes on goods and services & 1,182 & 1,467 & 1,913 & 2,696 & 2,948 & 3,337 & 3,559 & 3,797 \\
\hline Taxes on international trade & 5,209 & 2,630 & 2,881 & 2,865 & 3,711 & 4,035 & 4,556 & 4,861 \\
\hline of which: SACU receipts & 5,192 & 2,630 & 2,881 & 2,865 & 3,711 & 4,035 & 4,556 & 4,861 \\
\hline Other taxes & 15 & 25 & 57 & 61 & 65 & 69 & 74 & 79 \\
\hline Non-tax & 370 & 173 & 187 & 201 & 214 & 229 & 244 & 260 \\
\hline Grants & 120 & 296 & 265 & 225 & 239 & 255 & 281 & 281 \\
\hline Budget support & 0 & 0 & 0 & 0 & 0 & 0 & 0 & 0 \\
\hline Project grants & 120 & 296 & 265 & 225 & 239 & 255 & 281 & 281 \\
\hline Expenditures and net lending & 11,038 & 10,596 & 10,353 & 10,534 & 11,267 & 12,234 & 13,433 & 14,539 \\
\hline Current expenditures & 8,699 & 8,453 & 8,178 & 7,687 & 8,082 & 8,709 & 9,462 & 10,387 \\
\hline Wages and salaries & 4,420 & 4,900 & 4,208 & 4,141 & 4,091 & 4,231 & 4,513 & 4,815 \\
\hline Goods and services & 2,343 & 1,715 & 1,517 & 1,605 & 1,705 & 1,860 & 1,984 & 2,117 \\
\hline Subsides and transfer & 1,723 & 1,618 & 2,071 & 1,445 & 1,705 & 2,006 & 2,334 & 2,698 \\
\hline Interest & 213 & 220 & 382 & 496 & 581 & 611 & 630 & 756 \\
\hline Capital expenditure & 2,656 & 2,143 & 2,176 & 2,847 & 3,186 & 3,524 & 3,971 & 4,153 \\
\hline Foreign financed & 2,080 & 1,202 & 1,397 & 1,595 & 1,685 & 1,773 & 1,870 & 1,870 \\
\hline Domestic financed & 576 & 941 & 778 & 1,252 & 1,500 & 1,751 & 2,101 & 2,283 \\
\hline Net lending & -317 & 0 & 0 & 0 & 0 & 0 & 0 & 0 \\
\hline Exceptional Financing Transactions, Net & 0 & 0 & 0 & 0 & 0 & 0 & 0 & 0 \\
\hline \multicolumn{9}{|l|}{ Overall balance (commitment basis) } \\
\hline Including grants & $-1,816$ & $-3,542$ & $-2,373$ & $-1,607$ & -998 & -855 & -840 & -915 \\
\hline Excluding grants & $-1,936$ & $-3,838$ & $-2,638$ & $-1,832$ & $-1,237$ & $-1,110$ & $-1,121$ & $-1,196$ \\
\hline Accumulation of arrears & 0 & 1,200 & $-1,200$ & 0 & 0 & 0 & 0 & 0 \\
\hline Overall balance (cash basis) & $-1,816$ & $-2,342$ & $-3,573$ & $-1,607$ & -998 & -855 & -840 & -915 \\
\hline Financing $^{2}$ & 1,816 & 2,342 & 2,250 & 850 & 610 & 855 & 840 & 915 \\
\hline External financing (net) ${ }^{2}$ & 1,432 & 625 & 1,080 & 981 & 610 & 855 & 840 & 915 \\
\hline Domestic financing (net) & 385 & 1,718 & 1,170 & -130 & 0 & 0 & 0 & 0 \\
\hline Monetary Sector & 285 & 1,848 & 100 & 0 & 0 & 0 & 0 & 0 \\
\hline Non-Monetary Sector & 100 & -130 & 1,070 & -130 & 0 & 0 & 0 & 0 \\
\hline Privatization proceeds & 0 & 0 & 0 & 0 & 0 & 0 & 0 & 0 \\
\hline Errors and omissions/financing gap ${ }^{2}$ & 0 & 0 & 1,324 & 756 & 388 & 0 & 0 & 0 \\
\hline \multicolumn{9}{|l|}{ Memorandum item: } \\
\hline Primary balance, including grants & $-1,603$ & $-3,322$ & $-1,991$ & $-1,111$ & -417 & -244 & -210 & -159 \\
\hline Central government debt (gross) ${ }^{2}$ & 3,204 & 4,479 & 9,217 & 9,836 & 11,217 & 12,443 & 13,700 & 14,610 \\
\hline
\end{tabular}

Sources: Swazi authorities; and Fund staff estimates and projections.

${ }^{1}$ The fiscal year runs from April 1 to March 31.

${ }^{2}$ Financing gap assumed to be covered through foreign financing, which is included in the calculations of the stock of debt. 
Table 3. Swaziland: Fiscal Operations of the Central Government, 2009/10-16/17 ${ }^{1}$ (percent of GDP)

\begin{tabular}{|c|c|c|c|c|c|c|c|c|}
\hline & $2009 / 10$ & $2010 / 11$ & $\begin{array}{r}2011 / 12 \\
\text { Prog. }\end{array}$ & $2012 / 13$ & $2013 / 14$ & $2014 / 15$ & $2015 / 16$ & $2016 / 17$ \\
\hline & & & \multicolumn{6}{|c|}{ Projections } \\
\hline Total revenue and grants & 36.1 & 25.5 & 26.7 & 27.8 & 30.1 & 31.2 & 32.4 & 32.8 \\
\hline Revenue & 35.7 & 24.5 & 25.8 & 27.1 & 29.4 & 30.5 & 31.6 & 32.1 \\
\hline Tax Revenue & 34.2 & 23.8 & 25.2 & 26.5 & 28.8 & 29.9 & 31.0 & 31.5 \\
\hline Taxes on income, profits, and capital gains & 9.1 & 8.9 & 9.0 & 9.0 & 9.1 & 9.5 & 10.0 & 10.5 \\
\hline Taxes on goods and services & 4.6 & 5.3 & 6.4 & 8.4 & 8.6 & 9.1 & 9.1 & 9.1 \\
\hline Taxes on international trade & 20.4 & 9.5 & 9.6 & 8.9 & 10.9 & 11.1 & 11.7 & 11.7 \\
\hline of which: SACU receipts & 20.4 & 9.5 & 9.6 & 8.9 & 10.9 & 11.1 & 11.7 & 11.7 \\
\hline Other taxes & 0.1 & 0.1 & 0.2 & 0.2 & 0.2 & 0.2 & 0.2 & 0.2 \\
\hline Non-tax & 1.5 & 0.6 & 0.6 & 0.6 & 0.6 & 0.6 & 0.6 & 0.6 \\
\hline Grants & 0.5 & 1.1 & 0.9 & 0.7 & 0.7 & 0.7 & 0.7 & 0.7 \\
\hline Budget support & 0.0 & 0.0 & 0.0 & 0.0 & 0.0 & 0.0 & 0.0 & 0.0 \\
\hline Project grants & 0.5 & 1.1 & 0.9 & 0.7 & 0.7 & 0.7 & 0.7 & 0.7 \\
\hline Expenditures and net lending & 43.3 & 38.3 & 34.6 & 32.8 & 33.0 & 33.5 & 34.5 & 35.0 \\
\hline Current expenditures & 34.1 & 30.6 & 27.3 & 23.9 & 23.7 & 23.9 & 24.3 & 25.0 \\
\hline Wages and salaries & 17.3 & 17.7 & 14.1 & 12.9 & 12.0 & 11.6 & 11.6 & 11.6 \\
\hline Goods and services & 9.2 & 6.2 & 5.1 & 5.0 & 5.0 & 5.1 & 5.1 & 5.1 \\
\hline Subsides and transfers & 6.8 & 5.9 & 6.9 & 4.5 & 5.0 & 5.5 & 6.0 & 6.5 \\
\hline Interest & 0.8 & 0.8 & 1.3 & 1.5 & 1.7 & 1.7 & 1.6 & 1.8 \\
\hline Capital expenditure & 10.4 & 7.8 & 7.3 & 8.9 & 9.3 & 9.7 & 10.2 & 10.0 \\
\hline Foreign financed & 8.2 & 4.4 & 4.7 & 5.0 & 4.9 & 4.9 & 4.8 & 4.5 \\
\hline Domestic financed & 2.3 & 3.4 & 2.6 & 3.9 & 4.4 & 4.8 & 5.4 & 5.5 \\
\hline Net lending & -1.2 & 0.0 & 0.0 & 0.0 & 0.0 & 0.0 & 0.0 & 0.0 \\
\hline Exceptional Financing Transactions, Net & 0.0 & 0.0 & 0.0 & 0.0 & 0.0 & 0.0 & 0.0 & 0.0 \\
\hline \multicolumn{9}{|l|}{ Overall balance (commitment basis) } \\
\hline Including grants & -7.1 & -12.8 & -7.9 & -5.0 & -2.9 & -2.3 & -2.2 & -2.2 \\
\hline Excluding grants & -7.6 & -13.9 & -8.8 & -5.7 & -3.6 & -3.0 & -2.9 & -2.9 \\
\hline Accumulation of arrears & 0.0 & 4.3 & -4.0 & 0.0 & 0.0 & 0.0 & 0.0 & 0.0 \\
\hline Overall balance (cash basis) & -7.1 & -8.5 & -11.9 & -5.0 & -2.9 & -2.3 & -2.2 & -2.2 \\
\hline Financing $^{2}$ & 7.1 & 8.5 & 7.5 & 2.6 & 1.8 & 2.3 & 2.2 & 2.2 \\
\hline External financing (net) ${ }^{2}$ & 5.6 & 2.3 & 3.6 & 3.1 & 1.8 & 2.3 & 2.2 & 2.2 \\
\hline Domestic financing (net) & 1.5 & 6.2 & 3.9 & -0.4 & 0.0 & 0.0 & 0.0 & 0.0 \\
\hline Monetary Sector & 1.1 & 6.7 & 0.3 & 0.0 & 0.0 & 0.0 & 0.0 & 0.0 \\
\hline Non-Monetary Sector & 0.4 & -0.5 & 3.6 & -0.4 & 0.0 & 0.0 & 0.0 & 0.0 \\
\hline Privatization proceeds & 0.0 & 0.0 & 0.0 & 0.0 & 0.0 & 0.0 & 0.0 & 0.0 \\
\hline Errors and omissions/financing gap ${ }^{2}$ & 0.0 & 0.0 & 4.4 & 2.4 & 1.1 & 0.0 & 0.0 & 0.0 \\
\hline \multicolumn{9}{|l|}{ Memorandum items: } \\
\hline Primary balance, including grants & -6.3 & -12.0 & -6.7 & -3.5 & -1.2 & -0.7 & -0.5 & -0.4 \\
\hline Central government debt (gross) ${ }^{2}$ & 12.6 & 20.6 & 26.8 & 30.6 & 32.9 & 34.1 & 35.2 & 35.2 \\
\hline
\end{tabular}


Table 4. Swaziland: Monetary Accounts, 2009-16 ${ }^{1}$

(Emalangeni millions; unless otherwise indicated)

\begin{tabular}{|c|c|c|c|c|c|c|c|c|}
\hline & 2009 & 2010 & 2011 & 2012 & 2013 & 2014 & 2015 & 2016 \\
\hline & & & \multicolumn{6}{|c|}{ Projections } \\
\hline & \multicolumn{8}{|c|}{ I. Depository Corporation Survey } \\
\hline Net foreign assets & 7,763 & 5,629 & 6,534 & 7,570 & 9,276 & 11,160 & 12,055 & 12,744 \\
\hline Net domestic assets & -50 & 2,693 & 2,492 & 2,164 & 1,031 & -119 & -280 & -182 \\
\hline Claims on central government (net) & $-4,238$ & $-2,192$ & $-1,118$ & $-1,068$ & $-1,068$ & $-1,068$ & $-1,068$ & $-1,068$ \\
\hline Claims on private sector & 6,086 & 6,207 & 6,729 & 7,256 & 7,682 & 8,227 & 8,773 & 9,360 \\
\hline Other items (net) & $-2,323$ & $-2,006$ & $-3,312$ & $-4,324$ & $-5,901$ & $-7,584$ & $-8,311$ & $-8,820$ \\
\hline Broad money & 7,713 & 8,323 & 9,026 & 9,734 & 10,307 & 11,041 & 11,774 & 12,563 \\
\hline Currency in circulation ${ }^{2}$ & 328 & 358 & 451 & 487 & 515 & 1,656 & 1,766 & 1,884 \\
\hline \multirow[t]{2}{*}{ Deposits } & 7,386 & 7,965 & 8,574 & 9,248 & 9,792 & 9,385 & 10,008 & 10,678 \\
\hline & \multicolumn{8}{|c|}{ II. Central Bank } \\
\hline Net foreign assets & 5,828 & 3,840 & 4,476 & 5,351 & 6,926 & 8,908 & 9,653 & 10,182 \\
\hline Gross reserves & 6,479 & 4,496 & 5,198 & 6,129 & 7,750 & 9,791 & 10,595 & 11,187 \\
\hline Net domestic assets & $-4,523$ & $-2,668$ & $-2,939$ & $-3,032$ & $-3,490$ & $-4,107$ & $-4,533$ & $-4,720$ \\
\hline Claims on central government (net) & $-4,107$ & $-2,283$ & $-1,746$ & $-1,721$ & $-1,721$ & $-1,721$ & $-1,721$ & $-1,721$ \\
\hline Claims on private sector & 12 & 13 & 15 & 15 & 15 & 15 & 15 & 15 \\
\hline Claims on commercial banks & 2 & 3 & 5 & 5 & 5 & 5 & 5 & 5 \\
\hline Other items (net) ${ }^{3}$ & -431 & -403 & $-1,217$ & $-1,336$ & $-1,794$ & $-2,411$ & $-2,837$ & $-3,023$ \\
\hline Reserve money & 1,305 & 1,171 & 1,537 & 2,318 & 3,436 & 4,800 & 5,119 & 5,462 \\
\hline Memorandum items: & \multicolumn{8}{|c|}{ (12-month percentage change; unless otherwise indicated) } \\
\hline Reserve money & 38.3 & -10.2 & 31.2 & 50.8 & 48.2 & 39.7 & 6.6 & 6.7 \\
\hline M2 & 26.8 & 7.9 & 8.4 & 7.9 & 5.9 & 7.1 & 6.6 & 6.7 \\
\hline Credit to the private sector & 10.1 & 2.0 & 8.4 & 7.8 & 5.9 & 7.1 & 6.6 & 6.7 \\
\hline M2-to-GDP ratio (in percent) & 30.9 & 30.8 & 30.8 & 30.8 & 30.8 & 30.8 & 30.8 & 30.8 \\
\hline Money multiplier (broad money/reserve money) & 5.9 & 7.1 & 5.9 & 4.2 & 3.0 & 2.3 & 2.3 & 2.3 \\
\hline Credit to the private sector (in percent of GDP) & 24.3 & 22.9 & 22.9 & 22.9 & 22.9 & 22.9 & 22.9 & 22.9 \\
\hline Velocity (GDP/broad money) & 3.2 & 3.3 & 3.3 & 3.3 & 3.3 & 3.3 & 3.2 & 3.2 \\
\hline Gross international reserves to reserve money (in percent) & 496.5 & 383.8 & 338.1 & 264.4 & 225.6 & 204.0 & 207.0 & 204.8 \\
\hline $\begin{array}{l}\text { Gross international reserves minus reseve money, } \\
\text { in percent of domestic currency deposits }\end{array}$ & 70.1 & 41.7 & 42.7 & 41.2 & 44.1 & 53.2 & 54.7 & 53.6 \\
\hline
\end{tabular}

Sources: Swazi authorities; and Fund staff estimates and projections.

${ }^{1}$ End of period.

${ }^{2}$ Excludes rand in circulation.

${ }^{3}$ Including valuation changes. 
Table 5. Swaziland: Balance of Payments, 2009-16

(US\$ millions; unless otherwise indicated)

\begin{tabular}{|c|c|c|c|c|c|c|c|c|}
\hline & 2009 & 2010 & 2011 & 2012 & 2013 & 2014 & 2015 & 2016 \\
\hline & & & \multicolumn{6}{|c|}{ Projections } \\
\hline Current account & -416.1 & -652.1 & -493.4 & -388.1 & -290.8 & -198.1 & -192.9 & -204.6 \\
\hline Trade balance & -121.8 & -408.6 & -277.3 & -208.9 & -170.7 & -141.9 & -137.8 & -167.4 \\
\hline Exports, f.o.b. & $1,667.2$ & $1,763.5$ & $1,811.0$ & $1,825.7$ & $1,860.0$ & $1,919.5$ & $1,968.9$ & $2,076.5$ \\
\hline Imports, f.o.b & $-1,789.0$ & $-2,172.0$ & $-2,088.3$ & $-2,034.6$ & $-2,030.7$ & $-2,061.4$ & $-2,106.8$ & $-2,243.9$ \\
\hline Of which: oil & 288.8 & 372.6 & 420.4 & 427.8 & 437.4 & 450.7 & 463.2 & 480.0 \\
\hline Services (net) & -363.8 & -321.9 & -271.3 & -234.8 & -208.4 & -165.6 & -168.1 & -161.4 \\
\hline Income (net) & -123.2 & -7.9 & 8.1 & 16.5 & 26.2 & 36.4 & 29.2 & 31.9 \\
\hline Of which: interest on public debt & -21.5 & -23.0 & -25.8 & -36.4 & -45.3 & -47.8 & -52.7 & -59.5 \\
\hline Transfers & 192.7 & 86.3 & 47.1 & 39.1 & 62.1 & 73.0 & 83.9 & 92.3 \\
\hline Official transfers & 119.3 & 14.6 & -25.4 & -34.8 & -12.0 & -2.6 & 6.8 & 10.1 \\
\hline Other transfers & 73.4 & 71.7 & 72.5 & 73.9 & 74.1 & 75.6 & 77.1 & 82.2 \\
\hline Capital and financial account & 469.8 & 389.4 & 580.2 & 366.4 & 441.9 & 391.0 & 233.8 & 195.6 \\
\hline Capital account & -4.0 & 32.0 & 40.0 & 39.0 & 38.1 & 37.3 & 36.7 & 37.7 \\
\hline Financial account & 473.8 & 357.4 & 540.1 & 327.4 & 403.9 & 353.6 & 197.2 & 157.9 \\
\hline Foreign direct & 58.9 & 84.8 & 83.4 & 60.7 & 60.7 & 45.2 & 37.5 & 39.3 \\
\hline Portfolio investment & 116.7 & 23.8 & 18.1 & 18.5 & 18.5 & 18.9 & 19.3 & 20.6 \\
\hline Other investment & 298.2 & 248.8 & 438.6 & 248.2 & 324.7 & 289.6 & 140.4 & 98.1 \\
\hline Medium and long-term & 293.4 & 238.5 & 440.6 & 249.6 & 325.6 & 311.0 & 160.4 & 97.4 \\
\hline \multicolumn{9}{|l|}{ Of which: } \\
\hline Public sector (net) & -31.2 & -45.4 & 211.9 & 72.3 & 138.8 & 66.0 & 13.5 & -30.2 \\
\hline Disbursements & 0.0 & 154.9 & 255.7 & 127.5 & 211.9 & 155.4 & 118.2 & 91.4 \\
\hline Amortization & -31.2 & -200.3 & -43.8 & -55.2 & -73.1 & -89.4 & -104.7 & -121.6 \\
\hline Short-term & 4.8 & 10.3 & -2.0 & -1.4 & -0.9 & -21.4 & -20.0 & 0.7 \\
\hline Errors and omissions & -55.1 & 0.0 & 0.0 & 0.0 & 0.0 & 0.0 & 0.0 & 0.0 \\
\hline Overall balance & -1.5 & -262.6 & -66.2 & -21.7 & 151.2 & 192.9 & 40.9 & -9.0 \\
\hline \multicolumn{9}{|l|}{ Financing } \\
\hline $\begin{array}{l}\text { Net international reserves of the monetary } \\
\text { authorities }(-=\text { increase })\end{array}$ & 1.5 & 262.6 & -86.8 & -108.7 & -179.3 & -215.0 & -81.0 & -59.6 \\
\hline Exceptional financing & 0.0 & 0.0 & 0.0 & 0.0 & 0.0 & 0.0 & 0.0 & 0.0 \\
\hline Financing gap & 0.0 & 0.0 & 152.9 & 130.4 & 28.2 & 22.1 & 40.0 & 68.6 \\
\hline Memorandum items: & \multicolumn{8}{|c|}{ (percent of GDP) } \\
\hline Current account & -14.0 & -18.2 & -13.6 & -10.5 & -7.8 & -5.2 & -5.0 & -5.0 \\
\hline Trade balance & -4.1 & -11.4 & -7.6 & -5.7 & -4.6 & -3.8 & -3.6 & -4.1 \\
\hline Capital and financial account & 0.0 & 0.0 & 0.0 & 0.0 & 0.0 & 0.0 & 0.0 & 0.0 \\
\hline Overall balance & 0.0 & -7.3 & 2.4 & 2.9 & 4.8 & 5.7 & 2.1 & 1.4 \\
\hline Official grants & 4.0 & 0.4 & -0.7 & -0.9 & -0.3 & -0.1 & 0.2 & 0.2 \\
\hline Gross International Reserves & & & & & & & & \\
\hline$(\text { US \$ millions })^{1}$ & 878 & 596 & 643 & 716 & 857 & 1,032 & 1,067 & 1,127 \\
\hline (months of imports) & 3.9 & 2.6 & 2.9 & 3.4 & 4.1 & 4.9 & 5.0 & 4.9 \\
\hline National currency per US dollar & 8.4 & 7.6 & $\ldots$ & $\ldots$ & $\ldots$ & $\ldots$ & $\ldots$ & $\ldots$ \\
\hline
\end{tabular}


Appendix I-Letter of Intent

Mr. Dominique Strauss-Kahn

March 29, 2011

Managing Director

International Monetary Fund (IMF)

Washington, DC, USA

Dear Mr. Strauss-Kahn:

\section{RE: LETTER OF INTENT FOR AN IMF STAFF-MONITORED PROGRAMME}

Following several years of improved economic performance, the economy of the Kingdom of Swaziland has been hard-hit by the global economic crisis. Economic activity has slowed owing to a significant reduction in exports. In addition, fiscal pressures have mounted because of a sharp decline in revenues from the Southern African Customs Union (SACU) as well as structural imbalances in the budget. Medium-term prospects remain uncertain. Fiscal consolidation will take time, and our export potential may be negatively affected by possible removal of trade preferences (textile, preferential prices for sugar exports to the European Union), and the accession by Asian countries to similar preferences.

Against this background, Government has adopted policies, described in the attached Memorandum of Economic and Financial Policies (MEFP), for the period January 2011 to June 2011, which will make the first steps towards fiscal consolidation, while preserving developmental and poverty-reduction objectives. These policies complement the recent budget and are in line with our medium-term Fiscal Adjustment Roadmap (FAR), as well as our Poverty Reduction Strategy and Action Program (PRSAP).

In support of these policies, Government hereby requests a six-month Staff-Monitored Program, which could pave the way to a formal Fund arrangement later in 2011. Government will take any additional measure that may become necessary to maintain its fiscal consolidation objectives. Government will consult with IMF staff, at its own initiative or whenever the Managing Director of the IMF requests such a consultation, on the adoption of these measures and in advance of any revisions to the policies contained in the MEFP, in accordance with the IMF's policies on such consultations. Government will provide IMF staff with information related to progress made in implementing the program, as described in the Technical Memorandum of Understanding (TMU). The fiscal program for 2011/12 under the Staff-Monitored Program differs from the budget submitted to Parliament because Government plans a prudent execution of the budget based on available funds and in line with more conservative revenue projections recommended by the IMF. The budget also did not include the planned 5 percent reduction in the wage bill, which will further 
reduce the fiscal deficit and the proportion of spending going to the recurrent government Budget.

This letter of intent is signed by the Minister of Finance and the Governor of the Central Bank of Swaziland on behalf of Government after approval by Cabinet. Government authorizes the IMF to publish this letter, the attached MEFP and TMU, and the related staff report, including placement of these documents on the IMF website, subject to Fund policy on the removal of potentially marketsensitive information.

Yours sincerely,

/s/

/s/

Majozi Sithole

Minister of Finance

Martin G. Dlamini

Governor

Government of Swaziland

Central Bank of Swaziland 


\section{Attachment 1 -Memorandum of Economic and Financial Policies}

1. This memorandum sets out Swaziland's economic and financial policies for the period January 2011-June 2011, for which Government is seeking a six month IMF StaffMonitored Program (SMP). The program is anchored on two main objectives: (a) restoring fiscal sustainability and thus external sustainability; and (b) sustaining poverty reduction efforts, including by promoting a private-sector-led growth. The proposed SMP supports these development objectives as follows: (i) it aims to achieve macroeconomic stability through an orderly fiscal adjustment that addresses the permanent reduction in SACU revenues; (ii) it focuses on raising non-SACU revenues and improving public expenditure and financial management to focus the budget on key priority sectors, in particular the education and health sectors; and (iii) it seeks to accelerate structural reforms in order to increase productivity and competiveness which would facilitate higher economic growth. The program also protects the vulnerable by putting a floor on critical social expenditures, including on HIV/AIDS.

\section{Recent Economic DeVelopments}

2. Swaziland's recovery from the global economic crisis is being slowed down by the decline of some sectors and macroeconomic imbalances. Real GDP growth in 2010 is estimated to have been higher than in 2009 (2 percent vs. 11/4 percent), but remains below the precrisis level (about 3 percent on average). These lower growth performances reflect a marked decline in textile and wood pulp exports and a prolonged drought in 2009. As a result, the external current account is expected to have deteriorated significantly, from about 14 percent of GDP in 2009 to about 18 percent in 2010. Against this background, inflation has dropped from 71/2 percent in 2009 to 41/2 percent (year-on-year) in 2010, reflecting a moderate increase in food prices and falling international fuel prices.

3. The fiscal deficit is projected to reach about 13 percent of GDP in 2010/11 due to the decline in SACU revenues and historically high levels of expenditure. This deterioration can be largely explained by one of the highest public sector wage bills in Sub-Saharan Africa (close to 18 percent of GDP in 2010/11), and a sharp decline in SACU receipts from 201/2 percent of GDP in $2009 / 10$ to $91 / 2$ percent in 2010/11. Government anticipates this loss to be permanent, on current assumptions. Government has not been in a position to raise enough financing for the 2010/11 budget and has accumulated around E900 million in outstanding domestic payment arrears (31/2 percent of GDP) at end-December 2010.

4. The major vulnerability to the financial system in Swaziland stems from weakly supervised nonbank financial institutions (NBFIs), but efforts are underway to establish a regulatory system for these institutions. Otherwise, the financial sector has weathered the global economic crisis relatively well, and banks are well capitalized, profitable and liquid. 


\section{POLICIES UNDER THE SMP}

\section{A. Fiscal Policy}

5. Government has defined several fiscal objectives, in line with its Fiscal Adjustment Roadmap (FAR), which provide a guiding medium-term framework.

- $\quad$ Objective 1: To reduce the deficit to below 3 percent of GDP by 2014/15. Government intends to reduce expenditure over the medium term to a level consistent with a sustainable revenue stream. In this regard, Government will continue to reduce total expenditure (by cutting non-priority spending and the wage bill), and raise revenue through tax adjustments (such as introducing VAT and harmonizing some tax rates with South Africa) and through revenue administration improvements.

- $\quad$ Objective 2: To maintain the debt-to-GDP ratio at less than 40 percent over the medium term. Beyond this threshold, Swaziland risk of debt distress would rise rapidly.

- $\quad$ Objective 3: To strengthen public institutions in support of the FAR. By doing so, Government initially intends to (i) improve expenditure control, including by strengthening the role of the Ministry of Finance (MOF), which will have the core responsibilities for elaborating, implementing and monitoring the budget and its execution; and (ii) improve the ease and lower the cost of doing business in Swaziland.

- $\quad$ Objective 4: To continue making progress towards development objectives, including the United Nations Millennium Development Goals, and especially in the fight against HIV/AIDS.

\section{Measures Taken During the Fiscal Year 2010/11}

6. Because the level of expenditure is the main source of fiscal imbalance, Government has reduced in-year expenditure to contain the overall fiscal deficit in 2010/11 to E3.6 billion (13 percent of GDP) including arrears. The measures include:

- $\quad$ Cutting capital projects by around 30 percent. Capital expenditures have been reduced from $\mathrm{E} 2 \frac{1}{2} \mathrm{2}$ billion to 2 billion.

- $\quad$ Stopping overtime and introducing a hiring and wage freeze over the next three fiscal years. On the wage bill, Government has terminated non-statutory overtime pay (saving around E10 million) and implemented a hiring and wage freeze.

7. All new expenditure commitments have been stopped from November 15, 2010 until the end of the $2010 / 11$ fiscal year, except in the areas of education and health. This measure 
is expected to save at least E200 million in the 2010/11 budget (around 3/4 percent of GDP). Government has covered the additional cost (E350 million) incurred in November 2010 from the ongoing construction of the new Sikhuphe Airport by reducing commitments in other non-priority investment spending.

8. Some tax rates have been increased in line with those in the SACU region, and Government has taken major steps towards strengthening tax administration. The following changes have been adopted: (i) the fuel levy was increased by 50 cents per liter in three stages: first by 25 cents per liter for gasoline and diesel in November 2010; second by 10 cents per liter in February 2011; and third by 15 cents per liter in March 2011. This increase will yield around E100 million ( $1 / 4$ percent of GDP) in additional revenue annually. (ii) Excise duties on alcohol and cigarettes have been raised in line with the SACU region. (iii) The sales tax base has been broadened by removing exemptions on several products and services, including mobile phone services, which will now be taxed at the standard rate of 14 percent. Furthermore, the sales tax on tobacco and alcohol has been increased from 25 to 30 percent. Overall these measures are expected to raise around E150 million ( $1 / 2$ percent of GDP). These tax measures are being supported by the establishment of the Swaziland Revenue Authority (SRA) and the introduction of a Large Taxpayer Unit in January 2011.

9. Government has initiated the transformation of the Central Transportation Administration (CTA) into a public enterprise with its independent board and finances by June 2011 (structural benchmark). The CTA has become a significant drain on the budget, with transfers of around E400 million (11/2 percent of GDP) in 2010/11. Government has reduced this allocation to around E300 million in 2011/12 and intends to strengthen the monitoring of the CTA in the new fiscal year. Government will also submit legislation to Parliament in June 2011 to transform the CTA into a public enterprise (structural benchmark). As such, the CTA will be subject to quarterly reporting, and annual audited reporting. This is expected to improve the financial situation of the company and enhance transparency and accountability.

10. Immediate public financial management (PFM) reforms focus on strengthening expenditure controls. The MOF and the Central Bank have established a Cash-Flow Monitoring Committee with the responsibility of projecting and monitoring all cash inflows and outflows, and calculating the cash balance available for expenditures to be authorized centrally by the MOF. This Cash-Flow Monitoring Committee meets on a weekly basis. In addition, a commitment register has been set up in all ministries and departments, and commitments will be reported to the MOF on a monthly basis to help ensure compliance with budget allocations (structural benchmark). Thus, all priority expenditure will be authorized centrally by the MOF. Over the medium term, Government will continue to implement PFM reforms and the MOF will be restructured by establishing units to develop tax policy and to coordinate and improve debt management.

11. In addition, the new Public Financial Management Bill will be submitted to Parliament by end-June 2011 (structural benchmark). It lays out the functions, duties, and responsibilities of all budgetary institutions in the implementation of the budget. Proposed measures in the Bill include: adopting the International Public Sector Accounting Standards (IPSAS) across ministries; and consolidating expenditure reporting using IPSAS with the compilation and publication of 
quarterly budget execution reports with commentary on changes in revenue and expenditure against the approved budget; and timely production of final accounts (within three months of the end of the fiscal year).

12. The budget process has also been strengthened, with the core budget functions centralized with the MOF to ensure that fiscal policy objectives are met. Government has entrusted the MOF with all the powers to effectively design, implement, and monitor the budget process, including the capital budget, by disbanding the Planning and Budget Committee (PBC), as of 15 November, 2010 (prior action). The PBC has been replaced with bilateral discussions between the MOF and line ministries and departments. The Minister of Finance will have sole responsibility for setting binding expenditure ceilings for all line ministries and budget institutions. The Ministry of Economic Planning and Development and the Ministry of Public Service and Information will continue to advise the MOF on the appropriate expenditure allocations, but will not authorize such expenditures.

13. Government is aware of the rapid accumulation of domestic arrears. In this context, the MOF issued a budgetary circular on November 11, 2010, to instruct all line ministries and departments to begin reporting outstanding invoices to the Ministry of Finance on a monthly basis. Government is committed to clearing all domestic arrears accumulated in 2010/11 by end-March 2012.

\section{The 2011/12 Budget: the First Full Year of Fiscal Consolidation}

14. The 2011/12 Budget is a prudent one and makes further progress towards mediumterm targets set in the FAR. The main fiscal objective is to reduce the deficit to less than E2,373 million (around 8 percent of GDP), while preserving expenditure on education and health. It will be achieved through the full-year impact of increases in gambling tax and the fuel levy, the extension of the sales tax to mobile phone (and other) services at a rate of 14 percent, and higher sales tax rates on alcohol and tobacco (increasing from 25 to 30 percent), which will be effective in the first quarter of the fiscal year 2011/12. Transfers from the SACU revenue pool are projected to be E2,881 million. Overall, fiscal revenue, excluding grants is expected to raise around E7,715 million.

15. Government is committed to reducing the wage bill by 5 percent annually (E 240 million). The 2011/12 Budget already incorporates the wage and hiring freeze announced earlier, stopping notch increases (saving E25 million), as well as a reduction in allocations for travel and communication allowances (saving E30). Government also intends to reverse the 4.5 percent increase in wages granted in August 2010 through a staggered wage reduction to generate E240 million to the 2011/12 Budget and has engaged politicians and trade unions in negotiations to effect the reversal. As an upfront measure, Government agreed to cut the salaries of Cabinet ministers by 10 percent on March 22, 2011, and has made a public announcement to that effect. This will also reduce allowances for Cabinet ministers, which are a function of basic pay. The outcome of the negotiations with politicians and trade unions will be discussed at the time of the first assessment of the Staff-Monitored Program. The approval of the first assessment will be conditional on implementing measures sufficient to achieve the targeted reduction in the wage bill by E240 million in 2011/12 (structural benchmark for end-May 2011). Together with the steps 
already taken in 2010/11, Government expects these measures to reduce the wage bill by nearly E700 million to around E4,200 million (14 percent of GDP). In addition, goods and services and transfers will be rationalized, including through initiating steps to transform the CTA into a public enterprise. Overall, Government spending will be capped at E10,534 million in 2011/12. Over the medium term, the wage and hiring freeze will continue to remain in place, while the Enhanced Voluntary Early Retirement Separation (EVERS) packages will start yielding some positive savings on the wage bill.

16. Following the recommendations of the IMF technical assistance on revenue administration, Government will formulate a comprehensive taxpayer compliance strategy by September 30, 2011. To facilitate tax compliance, a comprehensive taxpayer registry will be developed covering all SRA operations with a single taxpayer identification number for each business unit. The SRA will also continue to make preparations for the introduction of the VAT scheduled for 1 April, 2012, including by submitting legislation to Parliament by end-June 2011 (structural benchmark).

17. PFM reforms will continue, with the improvement of the MOF website to strengthen fiscal transparency, and the development of a PFM action plan, based on IMF technical assistance recommendations, by June 2011. Government will post the medium-term policy statement, the Treasury Annual Report, the annual report on public enterprises, budget documentation for Parliament and the quarterly Budget Execution Report, starting April, 2011. Government will introduce amendments to the Audit Act by September 30, 2011, which will cover the following areas: (i) expand the Auditor General's auditing activities to include local Governments and public enterprises; (ii) apply the auditing standards of the International Organization of Supreme Audit Institutions (INTOSAI); and (iii) speed up the auditing of accounts to within 6 months following the end of the fiscal year. Government will also adopt an action plan, by September 30, 2011, to implement strategic PFM reforms.

18. Government's domestic resources are not expected to be sufficient to cover the overall Government deficit. In particular, the financing gap is expected to be about E11/2 billion. Government will seek additional external resources from donors to cover this financing gap. In parallel, exceptional financing may also come from the issuance of a second mobile network license and the privatization of Swazi Bank. Government has already taken steps towards the privatization of Swazi Bank and has approached consulting firms to provide an assessment.

19. Fiscal space created by containing spending and identifying new sources of tax revenue will be used to finance programs that best support economic growth and poverty reduction. These resources will be directed at curbing the spread of HIV/AIDS, improving education, and helping to achieve Government's objective of halving the poverty rate by 2015 . In this regard, Government has agreed to monitor the level of education and health expenditure under the Staff-Monitored Program, as indicated in the attached Technical Memorandum of Understanding. The efficiency of public spending will also be strengthened by improving the selection of investment projects. This will help underscore Government's commitment to prioritize projects in the areas of education, health, and infrastructure and help fulfill capital commitments in 
a timely manner. The implementation rate of capital spending will steadily increase, as project approval becomes dependent on a clear implementation schedule.

\section{Medium-Term Reforms}

20. Over the medium term, the expenditure and tax measures envisaged in the FAR are projected to yield savings of around 6 percent of GDP. The projected savings are as follows: (i) a wage and hiring freeze, coupled with a steady reduction in the number of civil servants (2 percent of GDP); (ii) cuts in goods and services (1 percent of GDP); (iii) continued improvements in tax administration (1 percent of GDP); (iv) introducing VAT at a rate of 14 percent, to be implemented in 2012/13 (1 percent of GDP); and ( $v$ ) revisiting tax policy with the aim of broadening the tax base through the removal of tax exemptions and the introduction of additional taxes (1 percent of GDP).

21. Growth will be led by the private sector, with Government providing a stable and attractive economic environment through: (i) sound macroeconomic management; (ii) a conducive investment climate; and (iii) a sound financial system. These measures will complement the Poverty Reduction Strategy and Action Program (PRSAP), adopted in 2007, which defines Government's strategy to halve the poverty rate by 2015.

\section{B. Monetary, Exchange, and Financial Sector Policies}

22. Objective 1: Preserving the viability of the fixed exchange rate system with gross reserves covering at least 3 months of imports and 200 percent of reserve money. Swaziland is part of the Common Monetary Area (CMA) with Namibia, Lesotho, and South Africa. The peg of the lilangeni at par to the rand has facilitated transactions with South Africa and helped maintain low inflation, which is expected to stabilize at around 5 percent over the medium term, broadly in line with inflation in South Africa. The Central Bank will maintain its monetary policy in line with that in South Africa in order to avoid any instability in the monetary and financial markets. The objective set on the level of gross international reserves will also go beyond the basic requirement of reserve money coverage. Setting the coverage at a level to cover reserve money fully as well as 50 percent of domestic currency deposits in commercial banks is in line with international best practice and will provide resources for contingencies, should unexpected stress on banks materialize. The coverage is expected to be largely achieved through the fiscal consolidation. However, the Central Bank will consider additional actions on reserve requirements in the event of an immediate and/or temporary need.

23. Objective 2: Raising the debt ceiling to provide additional financing resources to the budget and to develop financial markets. Deepening the money and capital markets is a key priority for Government. Indeed, owing to the limited availability of instruments to absorb excess liquidity, the Central Bank introduced Central Bank of Swaziland (CBS) paper with 182 days maturity in January 2011 to complement the existing 28-day and 56-day CBS bills and Government 91-day treasury bills already in the market. Government has amended the law defining the domestic debt ceiling to raise it to 25 percent of GDP from November 15, 2010 (prior action). Bonds will be issued to help finance the budget deficit for the remainder of 2010/11 and 2011/12. 
24. Objective 3: Strengthening the surveillance of non-bank financial institutions. Government passed the Financial Services Regulatory Authority Bill in 2010 to help address weaknesses in the supervision of savings and credit cooperatives (SACCOs), and other non-bank financial institutions (NBFls), including pension funds. To maximize its effectiveness, the bill will be implemented swiftly. A separate Securities Act enacted in December 2010 provides guidelines to improve the regulatory framework of the stock market and is expected to boost private sector investment by increasing the number of available investment instruments. Government has also requested assistance from the IMF to strengthen the surveillance of the financial sector.

25. Based on the forthcoming IMF safeguard, the Central Bank will develop an action plan to address all necessary measures to strengthen internal control systems. The recommendations of the safeguards assessment of the Central Bank will be the subject of the first assessment under the Staff-Monitored Program scheduled for May 2011.

\section{Improving Productivity and the Business Climate}

26. In order to strengthen private sector competitiveness, Government is pursuing a National Export Strategy (NES) to: (i) expand the export base with a focus on key areas such as food, forestry, horticulture, tourism and information technology; (ii) enhance market access through product branding and improved quality; (iii) improve trade facilitation through the establishment of strong public-private partnerships (PPPs); and (iv) restart the privatization process.

27. Government is committed to improving the business climate in order to attract increased private sector investment and create employment opportunities to reduce the high level of unemployment. To this end, Government is pursuing reforms that will make it easier to start, operate, and expand businesses. Government has already implemented a competition framework through the Competition Act and is in the process of streamlining licensing arrangements. Government is also considering incentives for FDI to enter the domestic market and exploit the comparative advantage held in commercial agriculture (sugar, cassava, cotton) and some niche agricultural areas (canned fruit, juice concentrates, and vegetables). Small claims courts will be established to strengthen investment protection for investors and reduce the backlog in court cases. An independent regulator will be set up to oversee competition in the telecommunications and information technology sector. In light of Swaziland's proximity to South Africa, Government will intensify efforts to take advantage of this large market as a way of developing the manufacturing industry through lower unit labor costs and a favorable investment climate for FDI. Efforts will also be made to further harmonize trade standards with those of South Africa to facilitate trade. The tight monitoring of public wages, as well as a prudent fiscal policy will preserve labor costs and reduce the cost of doing business in Swaziland.

28. Government will redouble its efforts to implement the 2004 privatization program. As a first step, preparations will be made to begin privatizing Swazi Bank in late 2011. Government will also shortly offer for sale a second network license to increase competitiveness in the telecommunications sector, reduce the cost of doing business and increase access to communication services for those on the lowest incomes. 
29. On the basis of these reforms, the medium-term growth profile is premised on the implementation of macroeconomic and structural reforms aimed at increasing competitiveness and achieving diversification. Real GDP growth is expected to decelerate from a projected 2 percent in 2010 to $1 / 2$ percent in 2011 on account of the sizeable fiscal adjustment in $2011 / 12$, but then rise to average $2 \frac{1}{2}$ percent per annum over the medium term. Growth will be underpinned by an expansion in private sector activities, complemented by public investment in health, education, and infrastructure.

\section{Risks ANd Contingency Plans}

30. Although there are signs of a regional and global recovery, some downside risks to the program remain. These risks relate to the pace of the global and regional economic recovery, and, a reduction in tariff rates due to trade liberalization and/or the creation of a SADC customs union as well as possible changes in the SACU revenue sharing formula, which is currently under discussion. If such risks were to materialize, Government, in close consultation with IMF staff, stands ready to take additional measures, while safeguarding social spending to ensure the achievement of a sustainable fiscal position and prevent a destabilizing reduction of gross international reserves.

\section{Program Monitoring}

31. The Staff-Monitored Program will have two assessments, one based on end-March 2011 targets and the second one based on end-June 2011 targets. Completion of the first and second assessments of the Staff-Monitored Program will be based on the observance of quantitative targets (Table 1) through end-March 2011 and end-June 2011, respectively, and a set of prior actions and structural benchmarks (Table 2). All prior actions have been completed. The variables monitored as quantitative targets are defined in the Technical Memorandum of Understanding (TMU).

32. Government is committed to ensuring that the program remains on track, and has set up a monitoring team, chaired by the Ministry of Finance, to monitor implementation. The monitoring team includes representatives of the Central Bank, the Swaziland Revenue Authority, and the Treasury. 
Table 1. Swaziland: Indicative Targets, 2010-11

\begin{tabular}{|c|c|c|c|c|c|}
\hline & \multirow{3}{*}{$\frac{2010}{\text { Dec. }}$} & \multicolumn{4}{|c|}{2011} \\
\hline & & Mar. & Jun. & Sep. & Dec. \\
\hline & & \multicolumn{2}{|c|}{ Program } & \multicolumn{2}{|c|}{ Projections } \\
\hline \multicolumn{6}{|l|}{ Indicative targets: } \\
\hline & \multicolumn{5}{|c|}{ (Emalangeni millions) } \\
\hline $\begin{array}{l}\text { Ceiling on the total financing } \\
\text { requirement of the central government }{ }^{1,2}\end{array}$ & 2,633 & 3,510 & 584 & 1,569 & 2,553 \\
\hline \multicolumn{6}{|l|}{ Ceiling on the net domestic assets } \\
\hline Floor on the central government social expenditures ${ }^{3}$ & 2,118 & 2,824 & 770 & 1,551 & 2,496 \\
\hline \multirow[t]{2}{*}{ Ceiling on the stock of domestic arrears } & 900 & 1,200 & 1,200 & 800 & 400 \\
\hline & \multicolumn{5}{|c|}{ (US\$ millions) } \\
\hline $\begin{array}{l}\text { Floor on the stock of net international } \\
\text { reserves of the Central Bank of Swaziland }{ }^{2}\end{array}$ & 548 & 437 & 476 & 600 & 639 \\
\hline Ceiling on the stock of external payments arrears ${ }^{4}$ & 0 & 0 & 0 & 0 & 0 \\
\hline \multicolumn{6}{|l|}{$\begin{array}{l}\text { Memorandum items: } \\
\text { Net disbursements } 1,2\end{array}$} \\
\hline General budget support & 0.0 & 0.0 & 40.0 & 75.0 & 100.0 \\
\hline \multirow[t]{2}{*}{ Debt service payments } & 142.5 & 190.0 & 52.5 & 105.0 & 157.5 \\
\hline & \multicolumn{5}{|c|}{ (Emalangeni millions) } \\
\hline SACU receipts ${ }^{1}$ & 2,138 & 2,630 & 720 & 1,440 & 2,160 \\
\hline \multicolumn{6}{|c|}{$\begin{array}{l}\text { Sources: Ministry of Finance and Development Planning; Central Bank of Swaziland; and Fund staff estimates. } \\
{ }^{1} \text { Values are cumulative from April } 1^{\text {st }} \text { (beginning of the fiscal year). } \\
{ }^{2} \text { Definitions and program adjusters are specified in the TMU. }\end{array}$} \\
\hline \multicolumn{6}{|c|}{${ }^{3}$ Includes spending on school feeding program, old age pension and HIV/AIDS } \\
\hline
\end{tabular}


Table 2. Swaziland: Prior Actions and Structural Benchmarks under the Staff-Monitored Program

Increase levy on gasoline, and diesel, to generate $\mathrm{E}$ 100 million in additional revenue on an annual basis

\section{Expenditure Cuts}

Stop all new budget commitments, except for health and education, for the remainder of 2010/11

\section{Budget process}

Abolish the Planning and Budget Committee.

\section{Financing}

Change the ceiling of domestic debt from $\mathrm{E} 1$ billion (4 percent of GDP) to 25 percent of GDP (about E 6.7 million)

\section{Benchmarks}

Expenditure Cuts

Implement measures to cut the public wage bill by E240 To restore fiscal sustainability million in nominal terms for the 2011/12 Budget.

\section{Public Financial Management}

Submission to Parliament of the Public Financial Management Bill

Establish a commitment register in all ministries and departments and report commitments on a monthly basis to the Ministry of Finance (for the current month and within budget allocations).

Submission to Parliament of legislation to convert the Central Transport Administration into a proper public enterprise with budget reporting requirements and oversight by the Ministry of Finance.

\section{Tax Policy}

Submission to Parliament of amendments to the Income Tax Order, in line with Fund staff recommendations.

Submission to Parliament of amendments to the Finance Act, in line with Fund staff recommendations.

Submission to Parliament of the VAT legislation

To achieve immediate revenue increases

Done on March 15, 2011

To stem expenditure overruns and achieve immediate expenditure cuts

To give Ministry of Finance the sole responsibility for elaborating, monitoring and executing the budget.

Reduce liquidity risks

Done on November 15 2010

Macroeconomic Rationale $\quad$ Test Date
end-May 2011

Strengthening PFM processes is key to end-June 2011 strenghten the control fo the Ministry of Finance over the budget. Improve expenditure controls and limit budget end-March 2011 overruns to make progress toward restoring fiscal and debt sustainability.

Rationalize expenditures to make progress toward restoring fiscal and debt sustainability

end-June 2011

Adjust tax policy to make progress toward

end-April 2011 restoring fiscal and debt sustainability.

Adjust tax policy to make progress toward end-June 2011 restoring fiscal and debt sustainability.

Improve efficiency of the tax system to make progress toward restoring fiscal and debt

end-June 2011 sustainability. 


\section{Attachment 2 - Technical Memorandum of Understanding}

1. This memorandum sets forth the understandings between Government of Swaziland and the IMF staff regarding the definitions of the quantitative targets and benchmarks for the Staff-Monitored Program (SMP), as well as the respective reporting requirements. These targets and benchmarks are reported in Table 1 and 2 of Government's Memorandum of Economic and Financial Policies (MEFP).

\section{A. Ceiling on the Total Financing Requirement (TFR) of the central Government}

2. Definition. The central Government includes the central administration and all district administrations. The total financing requirement of the central Government is defined as net credit to Government from the banking system (that is, the Central Bank of Swaziland and the commercial banks) plus holdings of treasury bills and other Government securities by the domestic nonbank sector and by foreigners. For program monitoring purposes, the financing requirement will be calculated as the change from end-December 2010 of net credit to Government by the banking system and of holdings of treasury bills and other Government securities by the domestic nonbank sector and by foreigners. In particular, the calculation of the financing requirement shall include changes in (i) balances held in the privatization account or balances of other accounts into which proceeds from the sale of public enterprises are deposited; (ii) the amount of outstanding treasury bills issued by the Central Bank of Swaziland for monetary policy purposes; and (iii) the balance of Government deposit account used by the Central Bank of Swaziland to sterilize reserve money absorbed by monetary policy operations. The calculation of the financing requirement shall exclude changes in balances held in any account into which revenues collected by the customs department are held pending their transfer to the SACU revenue pool. External debt service, amortization, disbursements and external grants will be calculated at an exchange rate of E 7 per US\$.

3. Supporting material. The Central Bank of Swaziland will provide the monetary survey and other monthly monetary statistics, as well as a table showing the details of all Government financing operations from the nonbank public, both domestic and foreign, on a monthly basis and within 30 days of the end of the month. The following information will be presented as memorandum items in the monetary survey: (i) the outstanding balances in the privatization account or accounts; and (ii) details of any monetary operations with treasury bills and other Government securities, including changes in Government deposits as a result of such operations. The Central Bank of Swaziland will also provide a table showing the details of Government debt by type and holder. The Ministry of Finance will provide detailed monthly budget operation reports and tax arrears reports.

\section{B. Ceiling on the Stock of Net Domestic Assets of the Central Bank of Swaziland}

4. Definition. The net domestic assets (NDA) of the Central Bank of Swaziland are defined as the difference between reserve money (currency in circulation plus total bank deposits at the Central Bank) and NFA (as defined in paragraph 5). The NDA thus includes net claims by the Central Bank of Swaziland on Government (loans, treasury bills and other Government securities 
purchased less Government deposits), claims on banks, and "other items net" (other assets, other liabilities, and the capital account).

5. Definition. The net foreign assets (NFA) of the Central Bank of Swaziland are defined as foreign assets minus foreign liabilities, and include all foreign claims and liabilities of the Central Bank. The values of all foreign assets and liabilities will be calculated in U.S. dollars at the end of each quarter using the program exchange rates.

6. Supporting material. The Central Bank of Swaziland will provide detailed data on its balance sheet on a monthly basis within 30 days of the end of the month. The Central Bank will also provide a table of selected monetary indicators covering the major elements of its balance sheet on a weekly basis.

\section{Floor on the Stock of Net International Reserves of the Central Bank of Swaziland}

7. Definition. The net international reserves (NIR) are defined as the Central Bank of Swaziland's liquid, convertible foreign assets minus its convertible foreign liabilities. Pledged or otherwise encumbered assets, including, but not limited to, assets used as collateral or as guarantee for third-party external liabilities are excluded from reserve assets. Reserve assets include cash and balances held with banks, bankers' acceptances, investments, foreign notes and coins held by the Central Bank of Swaziland, Swaziland's reserve position in the Fund, and SDR holdings. Reserve liabilities include nonresident deposits at the Central Bank of Swaziland, use of IMF credit, and any other liabilities of the Central Bank to nonresidents. The stock of NIR at the end of each quarter is defined in U.S. dollars and will be calculated using the program exchange rates. ${ }^{1}$

8. Supporting material. The Central Bank of Swaziland will provide data on its NIR on a monthly basis within one week of the end of the month. The NIR data will be provided in a table showing the currency breakdown of the reserve assets and reserve liabilities of the Central Bank of Swaziland converted into U.S. dollars and lilangeni at the program exchange rates.

\section{Ceiling on the Stock of External Payments Arrears}

9. Definition. During the period of the arrangement, the stock of external payments arrears of the public sector (central Government, Central Bank of Swaziland, and all enterprises with majority state ownership) will continually remain zero. Arrears on external debt-service obligations include any nonpayment of interest and/or principal in full and on time falling due to all creditors.

10. Supporting material. Details of arrears accumulated on interest and principal payments to creditors will be reported within one week from the date of the missed payment.

\footnotetext{
${ }^{1}$ Program cross exchange rates are: South African rand per US\$: 7; US\$ per pound sterling: 1.5; US\$ per euro: 1.3.
} 


\section{E. Ceiling on Domestic Arrears}

11. Definition: Domestic arrears are overdue payment obligations of the central Government other than external payment arrears, including on wages and salaries, pensions, transfers, domestic interest, goods and services, obligations arising from court cases, legally established compensation claims, and tax refunds. Payments on wages and salaries, pensions, transfers, court-established obligations, and compensations are in arrears when they remain unpaid for more than 45 days beyond their due date. Domestic interest payments are in arrears when the payment is not made on the due date. Payments for goods and services are deemed to be in arrears if they have not been made within 30 days of the date of invoice, or-if a grace period has been agreedwithin the contractually agreed grace period.

12. Supporting material: Information regarding domestic arrears is to be compiled in monthly reporting of invoices received and paid by all ministries to the Treasury according to the MOF Budget Circular CF/51. The audits will be completed and data will be submitted to IMF staff within 30 days of the end of each month.

\section{F. Floor on the Central Government Social Expenditures}

13. Definition: There will be a floor on the central Government social expenditures. The observance of this floor is an indicative target. Social expenditures comprise spending on the following programs: school feeding program, old age pension, and HIV/AIDS. The details of the targets for 2010-11 are indicated in the table below.

14. Supporting material: Data on social spending will be compiled by the Ministry of Finance and will be provided on a quarterly basis, to be submitted no later than six weeks after the end of each reporting period.

Swaziland: Social Expenditures, 2010-11

\begin{tabular}{|c|c|c|c|c|c|}
\hline & 2010 & \multicolumn{3}{|c|}{2011} & \multirow{3}{*}{ Dec. } \\
\hline & \multirow{2}{*}{$\begin{array}{r}\text { Dec. } \\
\text { Actual } \\
\end{array}$} & Mar. & Jun. & Sep. & \\
\hline & & Est. & $\overline{\text { Target }}$ & Benchmarks & \\
\hline & \multicolumn{5}{|c|}{ (Emalangeni millions) } \\
\hline Social Expenditures & 2,118 & 2,824 & 770 & 1,551 & 2,496 \\
\hline Education & 1,500 & 2,000 & 480 & 970 & 1,625 \\
\hline Health & 525 & 700 & 250 & 500 & 750 \\
\hline Other & 93 & 124 & 40 & 81 & 121 \\
\hline
\end{tabular}

G. Adjusters

15. The quantitative targets specified under the program are subject to the following adjusters:

- $\quad$ Southern African Customs Union Revenues. The program targets for the NIR in any quarter will be adjusted upward by the amount of Southern African Customs Union (SACU) 
receipts above Fund staff projections outlined in Table 1 of the MEFP. The program targets for NDA and TFR in any quarter will be adjusted downwards by the amount of SACU receipts above Fund staff projections outlined in Table 1 of the MEFP. Supporting material: The Central Bank of Swaziland will provide data on SACU receipts on a quarterly basis within the first month of the quarter.

- $\quad$ Budgetary Support net of Debt Service. ${ }^{2}$ The ceilings on NDA and TFR will be adjusted downward (upward) by the full amount of the delayed (advanced) budgetary support, net of debt service, relative to the programmed schedule specified in Table 1 of the MEFP. The floor on the NIR of the Central Bank of Swaziland will be adjusted upward (downward) by the full amount of the delayed (advanced) budgetary support, net of debt service, relative to the programmed schedule specified in Table 1 of the MEFP. Supporting material: Data on budget support and debt service will be compiled by the Ministry of Finance and will be provided on a quarterly basis, to be submitted no later than six weeks after the end of each reporting period.

- $\quad$ Payment of Arrears. The ceilings on NDA and TFR will be adjusted downward (upward) by the full amount of the excess (shortfall) in payments of arrears relative to the programmed stock levels specified in Table 1 of the MEFP. The floor on the NIR of the Central Bank of Swaziland will be adjusted downward (upward) by the full amount of the excess (shortfall) in payment of arrears relative to the programmed stock levels specified in Table 1 of the MEFP. Supporting material: Data on domestic arrears will be compiled by the Ministry of Finance and will be provided on a monthly basis, to be submitted no later than 30 days after the end of each month.

${ }^{2}$ General budget support consists of grants and concessional loans received by the central Government for financing its overall policy and budget priorities. 


\author{
INTERNATIONAL MONETARY FUND \\ KINGDOM OF SWAZILAND \\ Staff-Monitored Program - Informational Annex \\ Prepared by the African Department \\ (In consultation with other departments)
}

April 4, 2011

- $\quad$ Relations with the Fund. Describes financial and technical assistance by the IMF and provides information on the exchange rate system.

- JMAP Bank-Fund Matrix of Actions. Describes the priorities and main activities of the IMF and the World Bank Group, and areas of cooperation in their work with the Swazi authorities.

- $\quad$ Statistical Issues. Assesses the quality of statistical data.

- Social and Demographic Indicators. Provides an overview of key social indicators. 


\section{Contents Page}

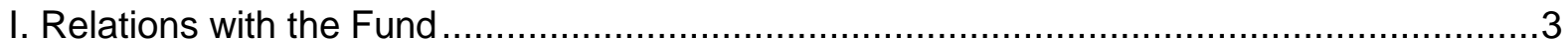

II. Swaziland: Bank-Fund Joint Management Action Plan .............................................

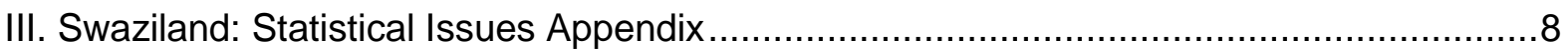

IV. Swaziland: Table of Common Indicators Required for Surveillance .................................

V. Swaziland: Social and Demographic Indicators......................................................10 
V. Relations With the Fund

(As of February 28, 2011)

I. Membership Status: Joined: September 22, 1969.

II. General Resources Account:

SDR Million

50.70

Percent Quota

Quota

44.15

100.00

Fund holdings of currency (Exchange Rate)

6.56

87.07

Reserve Tranche Position

SDR Million

12.94

III. SDR Department:

48.28

Percent Allocation

Net cumulative allocation

44.41

100.00

Holdings

91.97

IV. Outstanding Purchases and Loans: None

V. Latest Financial Arrangements: None

VI. Projected Payments to Fund 1/

(SDR Million; based on existing use of resources and present holdings of SDRs):

\begin{tabular}{lccccr} 
& \multicolumn{5}{c}{ Forthcoming } \\
\cline { 2 - 6 } Principal & $\underline{2011}$ & $\underline{2012}$ & $\underline{2013}$ & $\underline{2014}$ & $\underline{2015}$ \\
Charges/Interest & 0.01 & 0.02 & 0.02 & 0.02 & 0.02 \\
Total & 0.01 & 0.02 & 0.02 & 0.02 & 0.02
\end{tabular}

${ }^{1 /}$ When a member has overdue financial obligations outstanding for more than three months, the amount of such arrears will be shown in this section.

VII. Implementation of HIPC Initiative: Not Applicable

VIII. Implementation of Multilateral Debt Relief Initiative (MDRI): Not Applicable

IX. Implementation of Post-Catastrophe Debt Relief (PCDR): Not Applicable

\section{Exchange Rate Arrangement}

The lilangeni (plural: emalangeni) is pegged at parity to the South African rand, whichalongside the lilangeni-is also legal tender. The intervention currency is the U.S. dollar; exchange rates for the U.S. dollar are based on the floating middle rate of the South African rand against the U.S. dollar. The rate on February 28, 2010 was E1 = US $\$ 0.143599$.

Swaziland maintains an exchange restriction subject to approval under Article VIII arising from a 33.33 percent limit for advance payments for the import of certain capital goods.

\section{Article IV Consultation}

The last Article IV consultation was concluded on January 10, 2011. In concluding the consultation, In view of Swaziland's rapidly deteriorating fiscal position, Executive Directors stressed the need for urgent fiscal consolidation along with structural reforms in key areas to help achieve fiscal sustainability over the medium term, boost economic growth, and preserve external stability. 
XII. Technical Assistance, 2000-10

\begin{tabular}{|c|c|c|c|}
\hline Department & Purpose & Date of delivery & $\begin{array}{l}\text { Beneficiary } \\
\text { Agency }\end{array}$ \\
\hline \multirow[t]{4}{*}{ FAD } & Revenue administration & February 2011 & $\mathrm{MoF}^{6}$ \\
\hline & Public Financial Management & February 2011 & MoF \\
\hline & Revenue administration & March 2007 & MoF \\
\hline & Modernizing the Ministry of Finance & May 2009 & MoF \\
\hline \multirow[t]{4}{*}{ LEG } & Drafting of legislation on FIU & January 2004 & $\mathrm{CBS}^{7}$ \\
\hline & Exchange Control Regulations & April 2007 & CBS \\
\hline & Exchange Control Regulations & April 2007 & CBS \\
\hline & Follow up on $\mathrm{AML} / \mathrm{CFT}$ & December 2007 & CBS \\
\hline \multirow[t]{2}{*}{$\begin{array}{l}\text { LEG/MCM } \\
\text { (MFD) }\end{array}$} & $\begin{array}{l}\text { Review legal and supervisory frameworks } \\
\text { for AML/CFT }\end{array}$ & March 2004 & CBS \\
\hline & Follow mission on legislative drafting/FIU & May 2004 & CBS \\
\hline \multirow[t]{6}{*}{ MCM (MFD) } & $\begin{array}{l}\text { Strengthening the CBS, including monetary } \\
\text { and foreign exchange operations, the } \\
\text { payment system, and banking supervision }\end{array}$ & February 2011 & CBS \\
\hline & $\begin{array}{l}\text { Strengthening the CBS, including monetary } \\
\text { and foreign exchange operations, the } \\
\text { payment system, and banking supervision }\end{array}$ & February 2003 & CBS \\
\hline & $\begin{array}{l}\text { Development of the government securities } \\
\text { market, and the strengthening monetary } \\
\text { and foreign exchange operations }\end{array}$ & June-July 2003 & CBS \\
\hline & $\begin{array}{l}\text { Structure of NBFI supervision under FIRST } \\
\text { Initiative-funded TA }\end{array}$ & October 2003 & CBS \\
\hline & $\begin{array}{l}\text { Workshop for Senior Bank Supervisors in } \\
\text { East and Central Africa }\end{array}$ & July 2004 & CBS \\
\hline & $\begin{array}{l}\text { Foreign exchange operations and foreign } \\
\text { exchange reserves management }\end{array}$ & January 2005 & CBS \\
\hline \multirow[t]{7}{*}{ MCM(MFD) } & Long-term TA on reserves management & $\begin{array}{l}\text { Oct. 2005-April } \\
2006\end{array}$ & CBS \\
\hline & $\begin{array}{l}\text { Central bank accounting, central bank } \\
\text { organization and financial sector } \\
\text { supervision }\end{array}$ & November 2005 & CBS \\
\hline & $\begin{array}{l}\text { Supervision of saving and credit } \\
\text { cooperatives }\end{array}$ & April 2007 & CBS \\
\hline & Bank supervision, follow-up & August 2007 & CBS \\
\hline & Insurance and pension funds supervision & September 2007 & CBS \\
\hline & Supervision of insurance companies & November 2007 & CBS \\
\hline & Insurance supervision & January 2008 & CBS \\
\hline
\end{tabular}

\footnotetext{
${ }^{6}$ Ministry of Finance.

${ }^{7}$ Central Bank of Swaziland.
} 


\begin{tabular}{|c|c|c|c|}
\hline Department & Purpose & Date of delivery & $\begin{array}{l}\text { Beneficiary } \\
\text { Agency }\end{array}$ \\
\hline & Review Payment System & March 2008 & CBS \\
\hline & $\begin{array}{l}\text { Monetary operations, bank supervision, and } \\
\text { forex }\end{array}$ & April 2008 & CBS \\
\hline & Insurance supervision & April 2008 & CBS \\
\hline & Insurance supervision & June 2008 & CBS \\
\hline & Insurance supervision & July 2008 & CBS \\
\hline & Insurance supervision & November 2008 & CBS \\
\hline & Insurance supervision & February 2009 & CBS \\
\hline & Payments system Regional Advisor & February 2009 & CBS \\
\hline & Insurance supervision & April-May 2009 & CBS \\
\hline \multirow[t]{13}{*}{ STA } & Balance of Payment statistics & September 2010 & CBS \\
\hline & Participation in GDDS & July 2002 & MoF \\
\hline & Government Finance Statistics & July 2003 & MoF \\
\hline & $\begin{array}{l}\text { Balance of payments statistics/GDDS } \\
\text { Project for Anglophone Africa }\end{array}$ & October 2003 & CBS \\
\hline & $\begin{array}{l}\text { Government Finance Statistics/GDDS } \\
\text { Project for Anglophone Africa }\end{array}$ & October 2003 & MoF \\
\hline & $\begin{array}{l}\text { Government Finance Statistics/GDDS } \\
\text { Project for Anglophone Africa }\end{array}$ & June 2004 & MoF \\
\hline & $\begin{array}{l}\text { National Accounts Statistics/GDDS Project } \\
\text { for Anglophone Africa }\end{array}$ & July 2004 & $\mathrm{CSO}^{8}$ \\
\hline & $\begin{array}{l}\text { Consumer Prices Index/GDDS Project for } \\
\text { Anglophone Africa }\end{array}$ & October 2004 & CSO \\
\hline & $\begin{array}{l}\text { Monetary Statistics/GDDS Project for } \\
\text { Anglophone Africa }\end{array}$ & November 2004 & CBS \\
\hline & $\begin{array}{l}\text { Consumer Prices Index/GDDS Project for } \\
\text { Anglophone Africa }\end{array}$ & January 2005 & cso \\
\hline & $\begin{array}{l}\text { National accounts statistics/GDDS Project } \\
\text { for Anglophone Africa }\end{array}$ & April 2005 & cso \\
\hline & $\begin{array}{l}\text { Balance of payments statistics/GDDS } \\
\text { Project for Anglophone Africa }\end{array}$ & May 2005 & CBS \\
\hline & Consumer Prices Index/GDDS Project & May 2005 & $\mathrm{CSO}$ \\
\hline \multirow[t]{4}{*}{ STA } & $\begin{array}{l}\text { Consumer Prices Index/GDDS Project for } \\
\text { Anglophone Africa }\end{array}$ & September 2005 & CSO \\
\hline & $\begin{array}{l}\text { Balance of payments statistics/GDDS } \\
\text { Project for Anglophone Africa }\end{array}$ & October 2005 & CBS \\
\hline & $\begin{array}{l}\text { Government Finance Statistics/GDDS } \\
\text { Project for Anglophone Africa }\end{array}$ & November 2005 & MoF \\
\hline & $\begin{array}{l}\text { National accounts statistics/GDDS Project } \\
\text { for Anglophone Africa }\end{array}$ & October 2006 & cso \\
\hline
\end{tabular}

\footnotetext{
${ }^{8}$ Central Statistical Office.
} 


\begin{tabular}{|c|c|c|c|}
\hline \multirow[t]{13}{*}{ Department } & Purpose & Date of delivery & $\begin{array}{l}\text { Beneficiary } \\
\text { Agency }\end{array}$ \\
\hline & $\begin{array}{l}\text { Balance of payments statistics/GDDS } \\
\text { Project for Anglophone Africa }\end{array}$ & March 2006 & CBS \\
\hline & $\begin{array}{l}\text { Consumer Prices Index/GDDS Project for } \\
\text { Anglophone Africa }\end{array}$ & March 2006 & CSO \\
\hline & $\begin{array}{l}\text { Monetary Statistics/GDDS Project for } \\
\text { Anglophone Africa }\end{array}$ & March 2006 & CBS \\
\hline & $\begin{array}{l}\text { Consumer Prices Index/GDDS Project for } \\
\text { Anglophone Africa }\end{array}$ & July 2006 & CSO \\
\hline & $\begin{array}{l}\text { Balance of payments statistics and External } \\
\text { Debt/GDDS Project for Anglophone Africa }\end{array}$ & November 2006 & CBS \\
\hline & Consumer Prices Index & June 2007 & CSO \\
\hline & $\begin{array}{l}\text { National accounts statistics/GDDS Project } \\
\text { for Anglophone Africa }\end{array}$ & July 2007 & CSO \\
\hline & $\begin{array}{l}\text { Money and Banking Statistics/GDDS } \\
\text { Project for Anglophone Africa }\end{array}$ & November 2007 & CBS \\
\hline & $\begin{array}{l}\text { Government Finance Statistics/GDDS } \\
\text { Project for Anglophone Africa }\end{array}$ & July 2008 & MoF \\
\hline & $\begin{array}{l}\text { National Accounts Module mission/GDDS } \\
\text { Project for Anglophone Africa }\end{array}$ & October 2008 & CSO \\
\hline & $\begin{array}{l}\text { National accounts statistics/GDDS Project } \\
\text { for Anglophone Africa }\end{array}$ & March 2009 & CSO \\
\hline & $\begin{array}{l}\text { Money and Banking Statistics/GDDS } \\
\text { Project for Anglophone Africa }\end{array}$ & May 2009 & CBS \\
\hline
\end{tabular}


VI. SwaZILAND: BanK-Fund JoInt Management Action Plan

\begin{tabular}{|c|c|c|c|}
\hline Title & Products & Mission Date $^{1}$ & Delivery Date $^{1}$ \\
\hline \multicolumn{4}{|c|}{ A. Mutual Information on Relevant Work Program } \\
\hline $\begin{array}{l}\text { The World Bank } \\
\text { work program in } \\
\text { the next } 12 \text { months }\end{array}$ & $\begin{array}{l}\text { Country Partnership Strategy } \\
\text { Development Policy Operation } \\
\text { Rural Sector Review } \\
\text { JSDF-financed rural development pilot } \\
\text { project }\end{array}$ & $\begin{array}{l}\text { Consultation } \\
\text { Workshop (Q2 of } \\
\text { 2010) } \\
\text { Identification (Q4 } \\
\text { 2010) }\end{array}$ & $\begin{array}{l}\text { Q3 of } 2011 \\
\text { Q4 of } 2011 \\
\text { Q3 of } 2011 \\
2010-2014\end{array}$ \\
\hline $\begin{array}{l}\text { The Fund work } \\
\text { program in the next } \\
12 \text { months }\end{array}$ & $\begin{array}{l}\text { African Department } \\
\text { Assessments of the Staff } \\
\text { Monitored Program (SMP) } \\
\quad \text { Discussion on a follow-up IMF- } \\
\text { supported program } \\
\text { Technical Assistance } \\
\text { Safeguards Assessment } \\
\text { Revenue Administration follow-up }\end{array}$ & $\begin{array}{l}\text { May-11 } \\
\text { Sep-11 } \\
\text { Sep-11 } \\
\text { Apr-11 } \\
\text { Dec-11 }\end{array}$ & $\begin{array}{l}\text { Jun-11 } \\
\text { Nov-11 } \\
\text { Nov-11 } \\
\\
\text { Jun-11 } \\
\text { Mar-12 }\end{array}$ \\
\hline \multicolumn{4}{|c|}{ B. Requests for Work Program Inputs } \\
\hline $\begin{array}{l}\text { Fund request to } \\
\text { Bank }\end{array}$ & $\begin{array}{l}\text { Public Expenditure Review (PER) } \\
\text { Update } \\
\text { Debt Management Performance } \\
\text { Assessment (DePMA) } \\
\text { Cooperate on structural reforms in the } \\
\text { context of the discussions on an SMP }\end{array}$ & & $\begin{array}{l}\text { Q2 of } 2012 \\
\text { March-2011 }\end{array}$ \\
\hline $\begin{array}{l}\text { Bank request to } \\
\text { Fund }\end{array}$ & $\begin{array}{l}\text { Periodic macro updates } \\
\text { Cooperate on SMP design in the } \\
\text { context of the discussions on structural } \\
\text { reforms }\end{array}$ & & (continuous) \\
\hline \multicolumn{4}{|c|}{ C. Agreements on Joint Products and Missions } \\
\hline $\begin{array}{l}\text { Joint products in } \\
\text { next } 12 \text { months }\end{array}$ & $\begin{array}{l}\text { Bank staff to participate in IMF } \\
\text { missions to assess the SMP. }\end{array}$ & & $\begin{array}{l}\text { May-11 } \\
\text { Sep-11 }\end{array}$ \\
\hline
\end{tabular}

${ }^{1}$ Dates are tentative. Years are calendar years 


\section{SWAZILAND: Statistical ISSUES Appendix \\ (As of December 16, 2010)}

\section{Assessment of Data Adequacy for Surveillance}

General: Data provision has some shortcomings, but is broadly adequate for surveillance. Staff's analysis was affected by shortcomings in certain areas, including the national accounts and the external sector. The authorities provide available data to the Fund with a lag of one to three months, except for the national accounts, international trade data and the international investment position, which are reported irregularly.

Real sector statistics: STA GDDS missions have resulted in significant improvements in the national accounts. Current and constant price (base $=2000)$ GDP estimates are now available from both the production and expenditure approaches. These new estimates have not yet been published, as there are still some shortcomings concerning the treatment of Southern African Customs Union revenue. The authorities are planning the first labor force survey with support from the World Bank/GDDS project.

The consumer price index was significantly revised in May 2007 in the context of the GDDS initiative, incorporating improvements in compilation methodology, market basket coverage, flexibility for introducing new pricing outlets and new varieties of products, and enhanced processing capabilities. Four new geographical indices, as well as a national index, with updated market basket weights, are now available. Monthly consumer price data are published by the Central Statistical Office (CSO) with a one-month lag.

Monetary and financial statistics: Although some progress was achieved in the reporting of data on the other depository corporations (ODCs), quality problems remained, particularly in the areas of classification and sectorization. The majority of the ODCs reported various degrees of difficulty in providing accurate data to the Central Bank of Swaziland (CBS). Furthermore, the institutional coverage of the depository corporations' survey is limited, as it covers only the CBS and the commercial banks. Recently the CBS has started to include the Swaziland Building Society into the monetary data backdated to December 2006. The credit and savings cooperatives, representing about 8 percent of the deposits of the commercial banks, are still outside the deposit corporations' survey.

External sector statistics: Annual balance of payments statistics are compiled by the CBS according to a methodology consistent with the fifth edition of the Balance of Payments Manual (BPM5). However, shortcomings in the timeliness and availability of trade data impart a certain degree of uncertainty to external sector statistics and surveillance. The CSO publishes data on foreign trade on a quarterly basis, but the lack of sufficient computer resources results in long lags in the production of trade data, especially regarding imports. Further actions are required to improve the accuracy and reliability of external sector data.

\section{Data Standards and Quality}

Participant in the General Data Dissemination System (GDDS) since February 11, 2003.

No data ROSC is available.

\section{Reporting to STA}

The CBS reports monetary and financial statistics to STA regularly, although the timeliness of data could be improved. Balance of payments and international investment position data are published in International Financial Statistics (IFS) and in the Balance of Payments Yearbook. 
VIII. SWAZILAND: TABLE OF COMMON INDICATORS REQUIRED FOR SURVEILLANCE

(As OF DECEMBER 20, 2010)

\begin{tabular}{|c|c|c|c|c|c|}
\hline & $\begin{array}{l}\text { Date of } \\
\text { latest } \\
\text { observation }\end{array}$ & $\begin{array}{l}\text { Date } \\
\text { received }\end{array}$ & $\begin{array}{l}\text { Frequency } \\
\text { of } \\
\text { Data }^{7}\end{array}$ & $\begin{array}{l}\text { Frequency } \\
\text { of } \\
\text { Reporting }\end{array}$ & $\begin{array}{l}\text { Frequency } \\
\text { of } \\
\text { Publication }\end{array}$ \\
\hline Exchange Rates & Feb 11 & Mar11 & M & $\mathrm{D}$ & $\mathrm{D}$ \\
\hline $\begin{array}{l}\text { International Reserve Assets and } \\
\text { Reserve Liabilities of the Monetary } \\
\text { Authorities }^{1}\end{array}$ & Dec 10 & Feb 11 & M & M & M \\
\hline Reserve/Base Money & Dec 10 & Feb 11 & M & M & M \\
\hline Broad Money & Dec 10 & Feb 11 & M & M & M \\
\hline Central Bank Balance Sheet & Dec 10 & Feb 11 & M & M & M \\
\hline $\begin{array}{l}\text { Consolidated Balance Sheet of the } \\
\text { Banking System }\end{array}$ & Dec 10 & Feb 11 & M & M & M \\
\hline Interest Rates ${ }^{2}$ & Feb 11 & Mar11 & M & M & $\mathrm{D}$ \\
\hline Consumer Price Index & Feb 11 & Mar11 & M & M & M \\
\hline $\begin{array}{l}\text { Revenue, Expenditure, Balance and } \\
\text { Composition of Financing }{ }^{3}-\text { Central } \\
\text { Government }\end{array}$ & Jan 11 & Mar 11 & M & M & M \\
\hline $\begin{array}{l}\text { Stocks of Central Government and } \\
\text { Central Government-Guaranteed Debt }{ }^{5}\end{array}$ & Jan 11 & Mar 11 & A & A & A \\
\hline External Current Account Balance & 2009 & Sep 10 & A & A & A \\
\hline $\begin{array}{l}\text { Exports and Imports of Goods and } \\
\text { Services }\end{array}$ & 2009 & Sep 10 & Q & A & A \\
\hline GDP/GNP & 2009 & Sep 10 & A & A 2/3/ & A \\
\hline Gross External Debt & 2010 & Mar 11 & A & A & A \\
\hline International Investment Position ${ }^{6}$ & 2006 & Nov 09 & A & A & A \\
\hline
\end{tabular}

${ }^{1}$ Any reserve assets that are pledged of otherwise encumbered should be specified separately. Also, data should comprise short-term liabilities linked to a foreign currency but settled by other means, as well as the notional values of financial derivatives to pay and to receive foreign currency, including those linked to a foreign currency but settled by other means.

${ }^{2}$ Both market-based and officially-determined, including discount rates, money market rates, rates on treasury bills, notes and bonds.

${ }^{3}$ Foreign, domestic bank, and domestic nonbank financing.

${ }^{4}$ The general government consists of the central government (budgetary funds, extra budgetary funds, and social security funds) and state and local governments.

${ }^{5}$ Including currency and maturity composition.

${ }^{6}$ Includes external gross financial asset and liability positions vis-à-vis nonresidents.

${ }^{7}$ Daily (D), weekly (W), monthly (M), quarterly (Q), annually (A), irregular (I); and not available (NA). 
10

IX. SWAZILAND: SOCIAL AND DEMOGRAPHIC INDICATORS

\begin{tabular}{|c|c|c|c|}
\hline Area (sq. km.) & 17,364 & Population Density (per sq. km) & 65.47 \\
\hline Population & & Health & \\
\hline Total population (million) & 1.2 & & \\
\hline Population growth rate (percent) & 1.5 & Population per physician (2000) & 5,675 \\
\hline Life expectancy at birth (years) & 46 & $\begin{array}{l}\text { Public health expenditure (percent } \\
\text { of GDP) }\end{array}$ & 2.5 \\
\hline Infant mortality rate per thousand & 58.8 & & \\
\hline Urban Population (percent of total) & 24.4 & $\begin{array}{l}\text { HIV prevalence rate (ages 15-49, } \\
2000 \text { ) }\end{array}$ & 27.7 \\
\hline $\begin{array}{l}\text { Population younger than } 15 \\
\text { (percent of total population) }\end{array}$ & $\ldots$ & & \\
\hline GDP per capita (US\$) & 2,432 & Education & \\
\hline Access to safe water $(2000)$ & & Adult literacy rate (percent) & 86.5 \\
\hline Percent of total population & 59 & Primary school enrollment & \\
\hline Urban & $\ldots$ & (2005, percent) & 75 \\
\hline \multicolumn{4}{|l|}{ Rural } \\
\hline & & Poverty Indicators & \\
\hline \multicolumn{4}{|l|}{ Labor Statistics (thousands) } \\
\hline \multirow[t]{2}{*}{ Labor Force } & 338 & $\begin{array}{l}\text { Share of income, lowest } 20 \text { percent } \\
\text { (percent) }\end{array}$ & $\ldots$ \\
\hline & & GINI Index (2006) & 50.4 \\
\hline Formal Employment (2006) & 92 & & \\
\hline Private Sector & 65 & & \\
\hline Public Sector & 28 & & \\
\hline
\end{tabular}

Sources: International Financial Statistics; World Bank, World Development Indicators, April 2009, UNAIDS, 2006, 2006 Report on the Global Aids Epidemic; and national authorities. Data refer to 2008, unless otherwise indicated. 